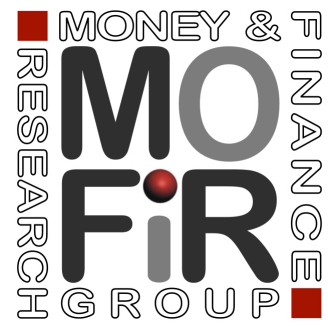

\title{
IMF LENDING AND BANKING CRISES
}

Luca Papi Andrea F. Presbitero Alberto Zazzaro

Working paper no. 80

February 2013 


\begin{abstract}
In this paper we look at the effect of International Monetary Fund (IMF) lending programs on banking crises in a large sample of developing countries, over the period 1965-2010. The endogeneity of the Fund intervention is addressed by adopting an instrumental variable (IV) strategy, in which the degree of political similarity between IMF borrowers and the G-7 is taken as an instrument for the likelihood of a country signing an IMF lending arrangement. Controlling for the standard determinants of banking crises, the IV estimates suggest that previous IMF borrowers are significantly less likely to experience a banking crisis. We also provide evidence suggesting that compliance with conditionality matters, consistent with the importance of IMF-supported financial reform, and that the positive effect of the Fund intervention on banking sector stability works through a direct liquidity provision effect.
\end{abstract}

JEL Codes: F33, F34, F35, O11

Keywords: Banking crises, IMF programs, Political economy

Acknowledgements: We thank Axel Dreher, Christopher Kilby and Gian Maria Milesi-Ferretti for providing data on IMF compliance with conditionality, UN votes and foreign assets and liabilities, respectively. The project was started when Andrea F. Presbitero was visiting scholar at the IMF. We wish to thank the Fund staff for providing historical data on the IMF lending arrangements and for useful guidance. We also thank participants at a seminar at the Graduate Institute (Geneva) and the Università Politecnica delle Marche for thoughtful suggestions.

Luca Papi

Andrea F. Presbitero

Alberto Zazzaro
Università Politecnica delle Marche (Italy) and Money and Finance Research group (MoFiR). E-mail: 1.papi@univpm.it.

Università Politecnica delle Marche (Italy) and Money and Finance Research group (MoFiR). E-mail: a.presbitero@univpm.it.

Università Politecnica delle Marche (Italy) and Money and Finance Research group (MoFiR). E-mail: a.zazzaro@univpm.it. 


\section{Introduction}

In this paper, we look at the effects of International Monetary Fund (IMF or Fund) lending programs on the risk of banking crises in borrowing countries and at the channels of influence of Fund interventions.

The mission assigned to the IMF by its founders in 1945 was limited to the promotion of exchange rate stability and the adjustment of external imbalances in member countries: to this end the IMF was to act as an intermediary between surplus and deficit countries and an arbiter of changes in par values between domestic currencies and the U.S. dollar. After the demise of the dollar exchange standard in 1973, the Fund had new sources of externalities to address and new public goods to provide (Bordo and James, 2000; Fratianni, 2003). Thus, the scope of IMF interventions has grown gradually, up to encompassing the much wider (and less welldefined) mission of the preservation of economic and financial stability in member countries. The Fund has pursued this objective both through its continuous country surveillance activity, involving policy recommendations and reform promotion, and by means of specific stabilization programs. The latter involve the disbursement of loans conditional upon the fulfillment of strict adjustment policies and economic reforms. According to the Fund's critics, however, the IMF lending policy is to be blamed for having imposed on recipient countries the inappropriate, ineffective and ideological economic recipes of the "Washington Consensus". In particular, the liberalization, privatization and austerity programs urged by the IMF in Mexico, South-East Asian countries, Russia and Brazil during the dramatic crises of the 1990s is thought to have triggered massive capital outflows and severe banking crises (Radelet and Sachs, 1998; Sachs, 2002; Stiglitz, 2002).

In response to these criticisms, and given the simultaneousness of currency and banking crises (Kaminsky and Reinhart, 1999), the Fund oriented its lending activity to the preservation of financial sector stability and to the prevention of liquidity crises. These targets have come back dramatically onto the Fund's agenda during the global financial crisis of 2007-09 and the successive sovereign debt crises in the eurozone that have engulfed banking systems and undermined the confidence of investors and financial markets worldwide. Many observers and scholars are now inclined to accept the idea that the IMF should be endowed with resources and instruments to credibly play the role of international lender of last resort (Fischer, 1999; Rogoff, 1999). In this perspective, a number of new lending facilities have been introduced by the Fund during the last fifteen years, giving to pre-qualified countries the opportunity to apply for precautionary credit lines. Upfront access to IMF resources would mitigate the vulnerability of countries with sound policies and institutions to sudden liquidity crises and self-fulfilling bank runs, avoiding the accumulation of costly international reserves (Rodrik, 2006; Joyce and Razo-Garcia, 2011).

Despite the intense debate about the responsibility of the Fund in the banking crises of the 1990s and the need to reshape its role and lending toolkit, we are not aware of any empirical study which analyzes the relationship between IMF-supported programs and the probability of systemic banking crises over the medium run.

The Fund's involvement in a country may have an impact on the probability of a banking crisis through a number of contrasting channels. First, IMF support is associated with the 
mobilization of financial resources, whose availability should prevent banking crises from materializing. The increase in financial flows may be the result of IMF direct interventions, which are usually meant to provide credit to bolster liquidity for the economy concerned, and of a catalytic effect on other official and private lenders (Bird and Rowlands, 2002; Cottarelli and Giannini, 2006). However, IMF loans might also drive investors to run to the limited amount of fresh liquidity, thus triggering a banking panic (Zettelmeyer, 2000).

Second, the Fund intervention may have either a positive or negative impact on the stability of the domestic banking industry through its direct and indirect effects on economic and financial reforms promoted through conditionalities.

Finally, IMF lending could bring negative side-effects on the risk of a banking crisis by inducing moral hazard on the part of both the borrowing country and its private creditors and via bad signalling.

In sum, whether and how IMF involvement affects the probability of a systemic banking crisis is an empirical question which might have different answers, depending on different sources of heterogeneity regarding loan size, conditionalities, lending arrangements and country's institutional environments. In this context, our contribution extends the recent empirical literature on the IMF's role in mitigating financial instability. This literature has investigated the effect of IMF-supported programs on sudden stops of financial capital flows (Eichengreen et al., 2008), on currency crises (Dreher and Walter, 2010), on sovereign debt crises (Jorra, 2012), and on the spread of the 2007-08 global financial crisis (Presbitero and Zazzaro, 2012).

Taking advantage of a large dataset covering 105 low- and middle-income countries over the period 1965-2010, we estimate the determinants of banking crises, focusing on the effect of the presence of IMF programs in previous years. The endogeneity of the Fund intervention is addressed by adopting an instrumental variable strategy, in which the degree of political similarity between IMF borrowers and the G-7 is taken as an instrument for the likelihood of a country signing an IMF lending arrangement in the five years before the crisis. Our main result is that, controlling for the standard determinants of banking crises, IMF member countries which have previously borrowed are significantly less likely to incur a banking crisis.

We then document that the negative correlation between IMF interventions and the likelihood of a banking crisis is significant only above a given loan threshold. This is consistent with the positive effect of the Fund's intervention on banking sector stability working through the direct liquidity provision effect, rather than indirect channels, such as the seal of approval effect. However, we also find that the effect of the Fund in reducing the incidence of banking crises is significantly stronger in recipient countries which are compliant with conditionalities attached to IMF-supported loans. This result would indicate that the positive effect of the Fund's intervention on banking sector stability also works through the reforms channel. Finally, we find that the positive impact of the Fund on the stability of the banking sector of the recipient country is conditional upon the presence of a sound institutional framework, but does not depend on the type (concessional versus non-concessional) of program signed with the country.

The remainder of the paper frames the research question in the theoretical and empirical literature about IMF support and financial stability (Section 2). Section 3 describes the empirical model to estimate, its main variables and their sources. Section 4 discusses the empirical find- 
ings and presents some robustness exercises. The concluding section summarizes our main findings and suggests possible extensions to be addressed by future research.

\section{Related literature}

The bulk of the theoretical and empirical literature on the role of the IMF in preventing financial crisis has referred to the effects of IMF-supported programs. In what follows, we briefly review this literature with special attention to the channels through which IMF lending programs may affect the probability of banking crises. At the risk of some over-simplification such channels can be grouped in three broad categories. First, the credit availability channel fuelled by both direct IMF lending and catalytic effects. Second, the reforms channel nourished by macroeconomic, structural and financial sector initiatives made possible by both the effect of direct IMF conditionality and the so-called scapegoat effect. Third, bad signals and moral hazard effects, which may increase risk taking and poor policies.

\subsection{IMF support and banking crises: the channels of influence}

\subsubsection{Credit availability}

A first strand of studies points out the positive effects of credit availability and countercyclical lending due to IMF intervention. First, once the program has been approved and credit disbursed, the amount of resources available to the country to be used to build up a certain level of emergency liquidity provision increases, thus reducing the probability of crises caused purely by illiquidity problems (Haldane, 1999; Miller and Zhang, 2000). Second, exploiting its position and reputation as most effective international lender of last resort (Rogoff, 1999; Fischer, 1999), a catalytic effect is indirectly exerted both towards other official lenders and the private sector (Bird and Rowlands, 2002; Cottarelli and Giannini, 2006). The existence of an IMF program acts as a seal of approval, reassuring investors and depositors and reducing the probability of withdrawing funds from the domestic banking sector. Similarly, IMF lending and partial bailouts may induce lenders to roll over their loans if the macroeconomic fundamentals of the member country are not too weak (Corsetti et al., 2006), and if the IMF intervention does not crowd out the adjustment effort of the member country government (Morris and Shin, 2006).

Several studies have explored empirically how an IMF-supported program could affect private capital flows, reaching mixed results (see Bird, 2007 and Steinwand and Stone, 2008 for a review). Bird and Rowlands $(2008,2009)$ cast doubt on the catalytic role of IMF-supported programs and show that net private capital inflows are negatively correlated with the presence of an IMF lending agreement, even if the average effect is heterogeneous across different capital flows and the initial conditions of recipient countries. In a similar vein, van der Veer and de Jong (2013) limit their analysis to countries that have not restructured their debt in the same year as their signing of an IMF program and show that the Fund's catalytic effect on private capital flows is significantly positive. ${ }^{1}$

\footnotetext{
${ }^{1}$ A related strand of literature has investigated how the existence of an IMF-supported program modifies interest
} 


\subsubsection{Conditionalities and financial reforms}

Since the 1990s, IMF conditionalities have increasingly concerned to policy actions directly related to financial reforms. Financial reforms sponsored by the Fund have comprised measures aiming to increase financial liberalization and improve the regulatory and supervisory framework. Whereas introducing financial liberalization without adequate banking sector surveillance might also contribute to banking sector fragility because it might increase opportunities for excessive risk-taking and fraudulent behavior, creating a more effective control system should instead make the banking sector more resilient, hence reducing the likelihood of systemic banking crises. Moreover, once a country has adopted a significant structural financial reform, the introduction of further reforming initiatives should become easier, through a sort of learning effect (Abiad and Mody, 2005).

Consequently, provided that conditionalities are correctly identified and properly implemented, the stability of the banking sector should be positively affected as a result of IMF intervention and countries more compliant with conditionalities should be less likely to experience banking crises. ${ }^{2}$ However, the positive role of conditionalities has been questioned both in theory and practice. According to this critical view, the IMF would not have access to all relevant information needed to design optimal policies in time of crises and, most important, the Fund policy advice would be influenced by the vested interests of its main shareholders. In this case, compliance with IMF conditionalities could trigger the spread of the crisis and aggravate the post-crisis collapse, as happened during the Southeast Asian financial crisis of the 1990s (Radelet and Sachs, 1998; Feldstein, 1998; Stiglitz, 2002).

Indirect and mixed evidence on the importance of reform channel is provided by DemirgucKunt and Detragiache (1998) and Kaminsky and Reinhart (1999), who find that financial liberalization is a determinant and a predictor of future banking crises. A more nuanced picture is provided by De Haan and Shehzad (2009), who find that most dimensions of financial reforms that enhance liberalization reduce the probability of systemic banking crises strictly conditional on adequate banking supervision.

\subsubsection{Bad signals and moral hazard}

Another strand of literature has focused on debtor and creditor moral hazard effects. First, country authorities might view IMF financial support as a substitute for their own adjustment effort (Jeanne and Zettelmeyer, 2001). In this case, IMF emergency loans weaken the incentives of national policy makers regarding their own adjustment effort, leading to laxer economic policies, IMF dependency (Vaubel, 1983; Goldstein, 2001), and in turn potential negative con-

rate spreads, both on commercial bank loans and on international bonds, and countries' debt maturity (Mody and Saravia, 2006; Saravia, 2010). Chapman et al. (2012) find that increasing the scope of conditionality attached to IMF programs reduces the yield on government bonds.

${ }^{2}$ In addition to what may be envisaged in the attached conditionality to a specific program, the IMF might facilitate the national authorities' effort to promote special financial reforms which, in the absence of IMF support, could be politically too difficult to implement due to opposition at home. Consequently, governments of member countries, by using the international financial institution as a scapegoat (Vreeland, 1999), may want to delegate responsibility for carrying out domestic unpopular reforms to the politically unaccountable IMF, deflecting towards the latter the possible blame for the resulting social and political costs (Haggard and Kaufman, 1995; Vreeland, 2003). 
sequences on banking stability.

Similarly, some sort direct and indirect creditor moral hazard may occur. First, to the extent that the IMF rescue package does not provide the member country with unlimited financial resources, investors might have incentives to liquidate their positions in the country and withdraw deposits from domestic banks (Zettelmeyer, 2000; Jeanne and Wyplosz, 2003). Second, anticipating a possible IMF bail-out in case of a crisis may lead markets to underprice sovereign risk in bond and equity markets, and investors to excessive risk-taking, making the crisis a more likely event (see Dreher, 2004 and Conway, 2006 for two excellent surveys of creditor moral hazard related to IMF lending). Finally, borrowing countries might suffer from some sort of stigma effect and turning to the IMF for crisis prevention might be interpreted by markets as signalling more severe troubles than hitherto publicly recognized.

\subsection{IMF support and financial crises}

To the best of our knowledge, there are no previous econometric studies analyzing the association between IMF-supported programs and banking crises. However, a limited number of recent papers have dealt with the role of the IMF in pursuing financial stability and preventing financial crises.

Eichengreen et al. (2008) document that countries, especially those with strong fundamentals, are less likely to experience sudden stops in international capital flows in the years following participation in an IMF program. The stabilizing role of the IMF emergency liquidity provision holds even after controlling for reverse causality.

Another piece of of evidence in favor of the positive role of IMF on the financial stability of member countries is presented by Dreher and Walter (2010) who find that the existence of an IMF-supported program in the previous five-year period reduces the probability of a future currency crisis. The authors analyze 68 developing countries over the period 1975-2002 and show that it is the lending agreement per se which drives the result, rather than the amount of the disbursed loan or the degree of compliance with conditionality.

Conversely, Jorra (2012), focusing on 57 developing and emerging economies over the period 1975-2008, shows that IMF-supported programs significantly increase the average probability of subsequent sovereign defaults by 1.4 percentage points. This is a meaningful effect, given a sample frequency of defaults of 4.8 percent. Like in Dreher and Walter (2010), however, this result does not seem to be due to lack of compliance with conditionality, but it reflects the effects of IMF interventions per se and suggests that the IMF intervention could trigger debtor moral hazard.

Finally, Presbitero and Zazzaro (2012) investigate whether, during the 2008-10 financial crisis, IMF lending was directed at preventing the risk of contagion, and whether participation in IMF programs was sensitive to the political-economic interests of the IMF's main shareholders. Their findings are mixed: on the one hand, political similarity with G7 countries is positively correlated with the probability of signing a loan agreement; on the other hand, the IMF has channeled more financial resources to those countries where the economic crisis was more severe. 


\section{Data and empirical strategy}

\subsection{The empirical model}

The empirical literature on the determinants of banking crises is quite extensive and, building on the influential paper by Demirguc-Kunt and Detragiache (1998), has identified some key variables which are correlated with a probability of banking crises. ${ }^{3}$ In Table 1 we briefly summarize the results from a non-exhaustive list of recent papers, pointing out also the sample covered and the methodology used. As is clear from the Table, almost all the studies consistently show that the likelihood of a banking crisis is higher when real interest rates and inflation are higher, after episodes of credit boom and when real GDP growth and the stock of international reserves are lower. This strand of literature has looked at the effect of several other explanatory variables, also considering the role of domestic institutions. However, so far it has ignored the potential role that international financial institutions (IMF, World Banks, etc.) could play in affecting the degree of domestic financial stability.

Henceforth, in what follows we assess the effect of IMF lending agreements on the probability of the occurrence of banking crises, drawing on an extensive data set covering 105 developing and emerging countries over the period 1965-2010.

The basic framework we use to look at the variables which may affect the incidence of banking crises is a pooled probit model (Demirguc-Kunt and Detragiache, 1998; Beck et al., 2006; De Haan and Shehzad, 2009). ${ }^{4}$ In particular, we estimate the following baseline model:

$$
\operatorname{Pr}\left(\text { BANKING CRISIS }_{i, t}\right)=\Phi\left(\text { IMF PRESENCE }_{i,(t-1, t-5)}, \text { CONTROLS }_{i, t-1}\right)
$$

where the probability of banking crisis in the i-th country at time $t$ is a function of the presence of the IMF in the country between $t-5$ and $t-1$ (IMF PRESENCE) and a set of standard macroeconomic control variables (CONTROLS), all one-year lagged.

The dependent variable is a dummy equal to one for country-year observations in which there is a systemic banking crisis (BANKING CRISIS). We adopt the methodology proposed by Laeven and Valencia $(2008,2012)$ and define a banking crisis episode as systemic when in a given year there are: 1) significant signs of financial distress in the banking system, and 2) major banking policy intervention measures in response to significant losses in the banking system. ${ }^{5}$

The key explanatory variable is a measure of the presence of a Fund-supported program in a given country in the five-year period before the crisis. In the baseline model, the presence of the Fund is measured by a dummy equal to one if country $i$ has signed at least one IMF lending arrangement in the five-year period before the onset of the banking crisis (IMF ARRANGEMENT). Alternatively, we consider a continuous measure, defined as the logarithm of the ratio between the amount of the loan, agreed between $t-5$ and $t-1$, and the country

\footnotetext{
${ }^{3}$ For a recent review, see Demirguc-Kunt and Detragiache (2005).

${ }^{4}$ Alternative estimation strategies rely on the use of a conditional fixed-effect model (Joyce, 2011) or a random coefficient logit model (Klomp, 2010). However, these models cannot be easily extended to address the endogeny of IMF lending.

${ }^{5}$ See Laeven and Valencia (2012, section 2) for more details on the actual definition of banking crisis episodes. Their Table A1 (p. 24) lists all the 147 systemic banking crises identified between 1970 and 2011.
} 
quota (IMF LOAN/QUOTA). ${ }^{6}$ The set of control variables is modeled on the basis of the main findings of the empirical literature discussed in Section 2.2. The list of variables, their labels, definitions and sources are reported in Table 2.

This empirical strategy may be weakened by two problems. First, we cannot fully exploit the panel dimension of the data set controlling for country fixed-effects, since they are perfect predictors of no default for countries which never had a debt distress episode in the sample period. The inclusion of country fixed-effects, therefore, would make it necessary to drop all countries without banking crises from the sample, leading to biased estimates. Moreover, country fixed-effects will wash-out much of the cross-sectional variation in the data that we would like to utilize to examine the effects of our institutional variables (on this, see also Noy, 2004; Aizenman and Noy, 2012). Hence, we will try to identify the effect of the IMF intervention on the likelihood of the crisis, controlling for a large set of explanatory variables.

Second, identification of the effect of participation in a Fund program on the probability of banking crisis using a simple probit model can be biased because of the potential endogeneity of the IMF agreement. Reverse causality may occur since the "crisis resolution role is at the core of IMF lending". 7 The Fund's presence in a country is more likely in crisis years or just before the onset of a crisis, when the government may ask the Fund for technical and financial assistance. In this case, however, the observed positive correlation between IMF lending and banking crisis would not imply any causation running from the former to the latter.

A further potential endogeneity problem is due to the fact that several macroeconomic variables, such as output growth, interest rates, and credit to the private sector, may be affected by the unfolding of the crisis. To minimize the impact of the banking crisis on the right-hand side variables we drop from the sample the years during which the crisis is spreading. ${ }^{8}$

\subsection{The IV strategy}

We tackle the endogeny of the IMF intervention by relying on an instrumental variable (IV) approach which has been widely used in the literature on IMF lending (Barro and Lee, 2005; Eichengreen et al., 2008; Dreher and Walter, 2010) and on banking crises (De Haan and Shehzad, 2009). We exploit the fact that the political similarity between borrowers and the IMF major shareholders is generally found to be a significant predictor of participation in a Fund loan agreement (Thacker, 1999; Oatley and Yackee, 2004; Barro and Lee, 2005; Barnebeck Andersen et al., 2006; Dreher et al., 2009; Presbitero and Zazzaro, 2012). The motivation of such correlation can be explained by the behavior of the Group of Seven (G7) governments, which trade their influence on the IMF Executive Board in exchange for support on important foreign policy issues discussed by the United Nations. The voting pattern in the United Nations General Assembly (UNGA) is taken as a proxy of the degree of similarity in foreign policy between

\footnotetext{
${ }^{6}$ We measure the loan amount as the agreed quantity, not the actual disbursement, because of data availability. This variable is set to zero if the country has not signed any agreement in the five-year period. For countries with more that one lending arrangement between $t-1$ and $t-5$, the loan amount (as a share of the quota) is the sum of the loan-to-quota ratios.

${ }^{7}$ See the IMF website at: http:/ / www.imf.org/external/about/lending.htm.

${ }^{8}$ We are helped in this task by the fact that Laeven and Valencia (2012) indicate in their data set the starting and ending year of each crisis. For the episodes which started in 2008, we assume that they are still ongoing in 2010, if no ending year is specified.
} 
IMF member countries and the Fund's major shareholders, namely the US and the other G7 countries. Hence, countries which prove to be aligned with the interests of G7 governments would be more likely to be rewarded by the IMF assistance.

In choosing the instrument set, we follow the approach proposed by Thacker (1999) and measure foreign policy similarity by two indicators. First, in line with the political proximity hypothesis, we calculate the average alignment score with G7 countries calculated on all UNGA regular votes (PROXIMITY_G7). ${ }^{9}$ This measure of political proximity between the country and the G7 has been widely used as a significant predictor of the presence of IMF lending arrangements (e.g., Oatley and Yackee, 2004; Barro and Lee, 2005). Second, in line with the political movement hypothesis, we consider the change in the average alignment score with G7 countries between $t$ and $t-1$ (MOVEMENT_G7). This variable should capture the possibility that it is the change in foreign policy orientation which would be rewarded by the major IMF shareholders, in line with the evidence provided by Thacker (1999). To take into account some persistence in the political process of concessions and rewards, both measures are time averages over the five-year period $(t-6, t-10)$ before the five-year period $(t-1, t-5)$ in which we allow for the possibility of a Fund lending program.

The soundness of our identification strategy is grounded in the validity of the instrument set. The relevance of our instrument should not be an issue, given the robust evidence mentioned in favor of a positive influence of political similarity between a country and the G7 governments (or the US) and the likelihood of signing of an IMF-supported program in that country in the following years. This correlation is confirmed also in our data set and, as we will show when discussing our results, the first-stage F-statistic is generally above the Stock and Yogo (2005) rule of thumb of 10, suggesting that we do not have a weak instrument problem. By contrast, the exogeneity of the instruments is in principle more questionable. Generally, political similarity variables have been used as instruments in growth regressions. In those cases, the excluding restriction is that the similarity in foreign policy orientation should not have a direct effect on countries' economic growth. When looking at financial stability, the excluding restriction is less tenable and it could be violated. In fact, it may be conceivable that political proximity with IMF shareholders also has direct influence on the stability of the financial sector in prospective recipient countries. If a reward mechanism exists, such that the G7 governments trade support for aligned votes in the UNGA, this support may take different forms besides the influence on the IMF Executive Board. Another possible form would be exerting influence on the domestic monetary and regulatory authorities or on foreign creditors in order to support and provide the banking system of G7 foreign policy friends with liquidity (Copelovitch, 2010a,b). ${ }^{10}$

\footnotetext{
${ }^{9}$ For a detailed description of the dataset, see Kilby (2009b). The data set also includes identification of important votes as declared by the US State Department. However, since this information is not available for the whole time span, we cannot construct the alignment scores based on important UNGA votes. Therefore, we cannot use the difference between the alignment score in important votes in the UNGA and the same score in all other UNGA votes, a measure introduced by Barnebeck Andersen et al. (2006). As in Thacker (1999) and Dreher and Jensen (2007), the alignment score of country $Y$ with country $X$ is measured considering, for each vote, that country $Y$ scores 1 if it follows $X, 0.5$ if it abstains or is absent when $X$ votes (or vice versa), and 0 if it opposes $X$. Political similarity with the G7 is built by averaging the pairwise annual alignment scores.

${ }^{10}$ It should be noted that a similar identification strategy based on friendships with IMF major shareholders has been followed to assess the impact of IMF-supported programs on the occurrence of other possible episodes of
} 
Being aware of the potential problems with our excluding restriction, we estimate an over identified model with both an IV probit and a 2SLS linear probability specification so that we can formally test for the validity of the over-identifying restrictions. As we will show below, the statistical tests indicate that our instruments are valid, such that we can apply our IV strategy to equation (1).

\subsection{Descriptives}

In the sample used in the baseline regressions (Table 4) there are 70 systemic banking crises, the first in 1976 and the last in 2009, and 455 IMF lending arrangements. Figure 1 shows the well-known concentration of bank distress episodes in the early 1980s and in 1990s, plus the recent events following the US subprime crisis and the global recession. IMF activity generally peaked around the crisis years. However, it is interesting to note that the Fund's financial support remained sustained (but declining) even after the late 1990s, without any significant banking distress episodes until the 2007 financial crisis. This is the period during which the focus of the Fund's activity on the reforms and stability of the financial sector became dominant. Hence, the diagram would suggest that the increased attention of IMF structural conditionality on banking sector stability and regulation after the 1997 Asian crises may have brought positive effects in terms of less vulnerability to systemic banking crises (Giustiniani and Kronenberg, 2005). ${ }^{11}$

Table 3 points out the positive association between banking crises and IMF-supported programs. In the whole sample of low- and middle-income countries, the likelihood of a banking crisis is equal to $5 \%$ in country-year observations in which an IMF program has been signed. This value is more than twice that in country-year observations in which there is no IMF loan agreement, and the difference between these two probabilities is statistically significant. The same pattern holds when we split the sample into low-income and middle-income countries.

Focusing on the 455 Fund lending arrangements present in our sample, we provide some additional information on the degree of compliance with conditionality and on the size of the loan. We follow Dreher and Walter (2010) and we code a country as compliant when at most $25 \%$ of the amount agreed under an IMF arrangement remained undrawn at program expiration. The size of the loan, instead, is normalized to the country quota at the IMF. ${ }^{12}$ Interestingly, only in one third of the programs for which we have data (140 out of 433 ) can countries be considered compliant with conditionality. The size of the loan is extremely variable, ranging from $5 \%$ to $1,560 \%$ of the country's IMF quota. The average (median) loan is equal to $130 \%(75 \%)$ of the quota and half of the loans are between $45 \%$ and $125 \%$.

financial crisis, like sudden stops of capital flows, currency and sovereign debt crises, for which the plausibility of the excluding restriction is equally questionable (Eichengreen et al., 2008; Dreher and Walter, 2010; Jorra, 2012).

${ }^{11}$ Giustiniani and Kronenberg (2005, p.11) note that "comparing the periods before (1995-96) and after (19972003) the Asian crisis, the share of banking sector conditionality has expanded from 65 percent to 80 percent of total financial sector measures [... and that this] is indicative of a growing and more comprehensive attention of IMF programs, and hence of IMF conditionality, to the functioning of the banking industry".

${ }^{12}$ The ratio between IMF loan and country quota is drawn directly from the IMF's historical data set. Unfortunately, we were not able to retrieve the nominal amount of the loan in current USD. 
Figure 1: Banking crises and IMF lending arrangements

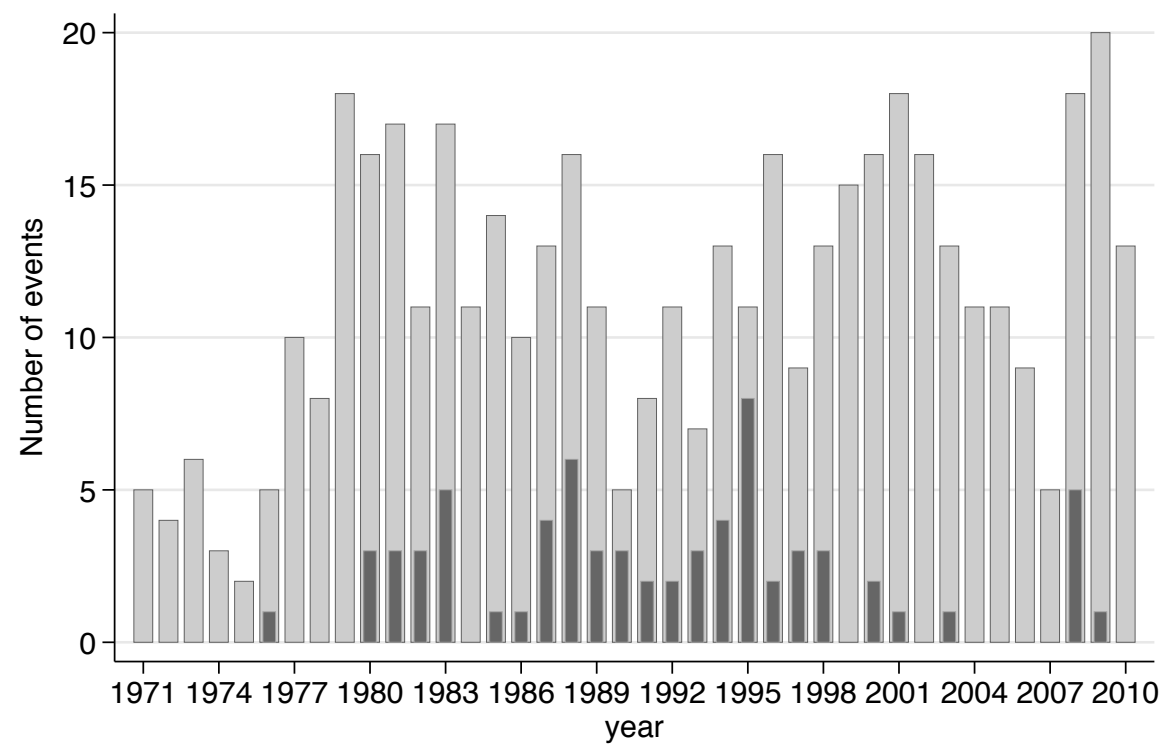

Number of IMF arrangements

Number of banking crises

Notes: Calculations based on Laeven and Valencia (2012) data set and on data on IMF lending arrangements. The sample consists of 2,527 country-year observations, as in the baseline regressions (see Table 4).

\section{Empirical results}

\subsection{Main findings}

The main results are reported in Tables 4 to 5, in which the presence of the Fund is measured, respectively, by a dummy equal to one if the country signed at least an IMF lending arrangement between $t-1$ and $t-5$ (IMF ARRANGEMENT $T_{t, t-5}$ ) and by the logarithm of the ratio between the amount of the loan resulting from the arrangement with the Fund and the country quota (IMF LOAN/QUOTA $t_{t-1, t-5}$ ). In both Tables, we report the results obtained estimating equation 1 using a standard probit, the IV probit and a 2SLS linear probability model.

The Wald test of exogeneity indicates that we can reject the null hypothesis of no endogeneity, supporting the necessity to adopt an IV strategy to identify the causal effect of the Fund intervention on banking sector stability. The first-stage coefficients on the excluded instruments (PROXIMITY_G7 $t-6, t-10$ and MOVEMENT_G7 $t-6, t-10$ ) and the diagnostic tests generally confirm that the instruments are relevant. They show a positive and significant correlation with the dummy for the IMF presence in the country in the interval $(t-1, t-5)$. More important, the F-test for the weak identification test is much larger than the 10 value proposed by Stock and Yogo (2005) as a rule of thumb. As regards the exogeneity, since the model is overidentified, we can run a standard Sargan-Hansen test of overidentifying restrictions, which indicates that we cannot reject the null hypothesis that our instruments are uncorrelated with the error term. Finally, the Kleibergen-Paap rk LM-statistic suggests that the model is not underidentified.

The results of Tables 4 to 5 are qualitatively similar. We start discussing the estimates in 
which the IMF intervention is measured by the dummy variable (Table 4). The first three columns report the estimates of equation 1 on the pooled sample. The non-IV probit estimates show that having signed an IMF lending agreement is not statistically correlated with the incidence of banking crises in subsequent years (column 1). However, when we take into account the potential endogeneity of IMF support, the coefficient on IMF ARRANGEMENT ${ }_{t-1, t-5}$ becomes negative and statistically significant, both in the IV probit and in the 2SLS estimates (columns 2 and 3). This result confirms the presence of a negative bias in the standard probit model (because of the negative correlation due to the IMF intervention in "bad times") and indicates that the Fund's assistance actually reduces the probability of incurring a banking crisis. The negative association between Fund intervention and the probability of banking crisis suggests that the positive effects of the IMF-supported program, in terms of credit availability and reform stimuli, offset the bad signals and moral hazard effects.

A similar picture emerges also when we drop the 2007-2010 period (columns 4-6), which may be considered a specific case because of the global recession, which significantly increased the number of banking crises, and the massive Fund interventions in several countries (see Figure 1). As anticipated, results are unaffected if IMF intervention is measured by the size of the loan (measured as a share of the country quota). Table 5 shows that the correlation between the size of the loan and the likelihood of banking crises is positive (and significant when excluding the 2007-2010 period), but becomes negative and significant once the endogeneity of the Fund support is taken into account.

Moving on to the set of control variables, we find that the occurrence of a banking crisis is robustly associated with fiscal imbalances (PUBLIC DEBT and SHORT TERM DEBT), real interest rates and changes in the real exchange rate and inflation. Specifically, our results indicate that the probability of a banking crisis is higher in more indebted countries and, especially, in countries with a larger fraction of short-term external debt. In addition, higher real interest rates are associated with a higher incidence of banking crises. As regards the monetary variables, we find that the coefficients on GDP DEFLATOR and DEPRECIATION are positive and significant (the former in the IV probit, the latter in the 2SLS estimates), suggesting that real exchange rate depreciation and higher inflation are leading indicators of a banking crisis.

Contrary to what is generally found in the literature, our results do not indicate that growth slowdowns are associated with a higher probability of crises (except in the 2007-2010 period), neither is real GDP per capita. This last finding is consistent with banking crises being an equal opportunity threat for poorer and richer countries (Reinhart and Rogoff, 2008). Similarly, we do not find any statistical association between the probability of banking crises and the measure of de jure financial openness, credit growth, and the ratio of M2 over international reserves (in this case the coefficient is positive and statistically significant, as expected, only in the standard probit estimates).

\subsection{The credit channel}

As discussed in Section 2.1, the positive influence of Fund intervention on banking sector stability may be due to credit availability and the reform channels. We will address the role of conditionalities and reforms in the next section. Here we focus on credit availability and aim 
to see whether there is some non-linearity on the effect of IMF intervention according to the size of the loan.

To test for the role of credit availability we consider the possibility of nonlinear effects of IMF interventions on the likelihood of banking crises. The idea is that if the provision of a sufficiently large amount of financial resources were not a necessary element to nurture the confidence of creditors and create a safety net for the domestic banking system, the effect of an IMF-supported program would be independent of its size. Otherwise, the intervention of the Fund per se is not sufficient to reduce the risk of banking crises, unless it exceeds a certain size threshold.

Empirically, we split the sample according to the size of the IMF loan at some specific exogenous threshold. Given the non-linearity of our model and the endogeneity of the key regressor, we are unable to implement more sophisticated methods used to test for the presence of an endogenous threshold (Hansen, 2000). However, we try to mitigate the effect of the arbitrariness in the choice of the threshold, splitting the sample for any value of the loan amount (as a percentage of the country quota at the IMF) in the range $[40-120]$, with 10 percentage point increments. ${ }^{13}$ In Table 6 we report the estimated coefficients of the key variable IMF ARRANGEMENT $_{t-1, t-5}$ for the different sub-samples, together with the first-stage coefficients on the excluded instruments.

The results indicate that up to the 80 percent threshold the likelihood of a banking crisis is significantly smaller only for sufficiently large loans. By contrast, when considering loans larger than 80 percent of the country quota, the coefficient on IMF ARRANGEMENT AR $_{t, t-5}$ is negative and statistically significant both below and above the quota. Thus, our results suggest that, as long as the loan amount is sufficiently small (below $80 \%$ of the country quota), IMF lending does not reduce the probability of banking crises. In other words, only significantly large IMF loans are associated with a lower probability of banking crises.

One may argue that this non-linearity is the result of a model mis-specification. However, the first-stage coefficients on the instrumental variables indicate that the lack of significance of the lending arrangement dummy in the small loan samples should not depend on the limited power of the instruments. That said, the lack of significance of the IMF dummy may still depend on the sample being relatively small (see columns 1,3 and 5). However, comparing the sample split around the 70 and 80 percent thresholds (columns 7-10) with the split around the 90, 100 and 110 percent thresholds should make it clear that the significance of the coefficients does not depend on the number of observations in each sub-sample.

As we have seen, the credit availability channel may be the result of direct liquidity support from the Fund and of indirect effects related to the Fund's provision of a seal of approval and to a catalytic effect on private and public investors. The evidence that larger loans have a stronger effect in reducing the occurrence of banking crises could be read as consistent with the presence direct liquidity provision effect of IMF-supported programs on banking sector stability.

\footnotetext{
${ }^{13}$ We choose such a threshold range since we are not interested in tails of the sample distribution of the IMF LOAN/QUOTA variable. A loan to quota ratio of $40 \%(120 \%)$ roughly corresponds to the $15^{\text {th }}\left(67^{\text {th }}\right)$ percentile of the sample distribution of the IMF LOAN/QUOTA variable.
} 


\subsection{The conditionality/reform channel}

Other than credit availability, IMF intervention could affect banking sector stability thanks to the conditions and policy advice coming along with IMF-supported programs. In particular, the conditionalities targeting on financial sector reforms may affect the likelihood of a future banking crisis, making the financial sector more resilient to international capital flows and external shocks (see above, sub-section 2.1.2). However, the effectiveness of IMF conditionalities depends on the degree of compliance of the recipient country (Dreher, 2009). Focusing specifically on financial sector conditionalities, Giustiniani and Kronenberg (2005) find that compliance with IMF-supported banking sector reform strategies has contributed to an improvement in banking sector performance over the period 1995-2003.

Unfortunately, since the MONA data set classifies compliance by conditionality categories starting from 1992, we could look at financial-sector conditionalities only at the expense of a dramatic reduction of our sample. Therefore, we consider the general degree of compliance with conditionality as coded by Dreher and Walter (2010). The results, shown in Table 7, indicate that the positive effect of IMF-supported programs on the probability of a future banking crisis critically depends on compliance with conditionality. Differently from the evidence found on the outbreak of currency and sovereign debt crises, which point to a limited importance of the distinction between compliers and non-compliers (Dreher and Walter, 2010; Jorra, 2012), we find that the effect of the IMF lending arrangement in reducing the probability of banking crises is much lower for countries which are not compliant with the Fund's conditionality. The effect of the compliance is economically significant. Considering the 2SLS estimates (column 3), the probability of banking crisis is $18.9 \%$ lower for countries which signed an IMF lending agreement and were compliant with the Fund's conditionality. A lending agreement, but without compliance, instead, lowers the probability of banking crisis only by $6.8 \%$.

\subsection{Concessional vs non-concessional loans and the role of the macroeconomic and institutional framework}

Pooling all countries in the sample may mask some sort of heterogeneity and may lead to inconsistent estimates. Thus, in Tables 8 and 9 we assess whether the effect of the IMF intervention differs according to the kind of IMF arrangement and the macroeconomic and institutional characteristics of borrowing countries.

First, in Table 8 we split the sample between non-concessional loans, financed via the General Resources Account (GRA), and concessional loans, extended from the Poverty Reduction and Growth Trust (PRGT, which recently replaced the Poverty Reduction and Growth Facility PRGF). We do not find any significant difference in the effect of Fund interventions on banking stability across arrangement type. Our IV strategy proves valid in the two sub-samples and the IV estimates show that both concessional and non-concessional IMF-supported programs are associated with a lower probability of banking crises.

In Table 9 we report the sample splitting along several dimensions of the macroeconomic and institutional framework, all commonly used in the economic and political science literature. We start by splitting the sample according to a measure of the degree of a country's 
political, financial and economic riskiness (COUNTRY RISK). This risk rating is the Composite Index published by the International Country Risk Guide (ICRG). ${ }^{14}$ We observe that the effect of IMF intervention is significant only in countries with a sound institutional framework (defined as countries where the ICRG score is above the sample median, see Table 9, columns 1 and 2). This evidence would be consistent with the hypothesis that the catalytic effect of the Fund is stronger and the risks of moral hazard are lower in countries with good policies and institutions. However, this result is not robust to alternative definitions of the institutional setting (see columns 3 to 8). First, we consider the index of access to sound money (SOUND MONEY), published by the Fraser Institute as part of the Economic Freedom of the World Index. This variable measures the growth rates of money supply and inflation, and the freedom to own foreign currency bank accounts domestically and abroad. ${ }^{15}$ Second, we use the polity score from the Polity IV data set (POLITY), which ranks governing institutions from autocratic to democratic according to measures that record key qualities of executive recruitment, constraints on executive authority, and political competition (Marshall et al., 2010). Third, we rely on the dummy DEMOCRACY, which identifies democracies and dictatorships according to the definition proposed by Cheibub et al. (2010). ${ }^{16}$ In all these three sample splits, we find that the coefficients on the dummy for the IMF arrangement are negative and statistically significant in both sub-samples. Furthermore, the magnitude of the coefficients is generally quite similar, apart from columns 7 and 8, in which the effect of the IMF presence seems larger in democracies than in dictatorships.

In sum, while the effectiveness of the Fund-supported programs in bolstering banking sector stability seems to be impaired by a weak institutional framework, we do not find robust evidence that a stable monetary environment and the presence of democratic institutions are necessary conditions for the Fund presence to mitigate the risk of a future banking crisis.

\subsection{Controlling for other potential triggers of banking crises}

As a robustness exercise we expand the set of control variables to take into account other possible determinants of banking crises. We add three sets of additional explanatory variables. First, we control for the occurrence of currency crises in the previous year, for the history of past banking crises, and for the presence of a deposit insurance scheme. Second, we augment the model with a measure of the degree of financial liberalization and with for three measures of financial integration. Finally, we include the measures of institutional quality and democracy which we used to inspect the possible heterogeneity of the effect of the Fund. Table 10 reports the results of the IV probit estimation of Equation 1 and shows that the coefficient on IMF ARRANGEMENT $_{t-1, t-5}$ is robust to the inclusion of these additional control variables.

The results reported in columns 1 and 2 support the existence of a close link between balance-of-payment and banking crises (Kaminsky and Reinhart, 1999), but they do not in-

\footnotetext{
${ }^{14}$ The Composite Index is a risk rating based on a set of 22 components grouped into three major categories of risk: political, financial, and economic. The index ranges between 0 and 100, with higher values indicating lower levels of risk. For details, see http:/ / www.prsgroup.com.

${ }^{15}$ See: http:/ / www.freetheworld.com/index.php and Gwartney et al. (2012) for details.

${ }^{16}$ The sample was split by taking the median of the economic freedom index as thresholds (columns 3-4), the value of zero for the polity index (columns 5-6) and the $0 / 1$ value of the dummy identifying democracies (columns 7-8).
} 
dicate that countries that have already experienced at least one banking crisis in the previous decade (BANKING CRISES $_{t-1, t-10}$ ) have a higher likelihood of experiencing another crisis, contrary to what was found by Aizenman and Noy (2012) who, however, focus on a smaller sample. The occurrence of a currency crisis in $t-1$ (CURRENCY CRISIS ${ }_{t-1}$ ) significantly raises the probability of a banking crisis: the average partial effect associated with the estimates reported in column 1 indicates that countries with a currency crisis in $t-1$ are $4.2 \%$ more likely to experience a banking crisis.

The coefficient on the dummy for country-year observations in which a deposit insurance scheme is in place (DEPOSIT INSURANCE, column 3) shows that the presence of a deposit insurance induces moral hazard, since it is positively correlated with the likelihood of a banking crisis, as in Demirguc-Kunt and Detragiache (1998).

In column 4 we control for the degree of financial liberalization (FINANCIAL REFORMS), as measured by an index of financial reforms compiled by Abiad et al. $(2008)^{17}$, but we do not find that the likelihood of banking crises differs across the degree of financial liberalization. Given the lack of significance of de jure measures of financial openness (see Table 4) and financial liberalization, in column 5 we also control for de facto financial integration, as measured by the ratios over GDP of: (i) portfolio equity liabilities (PORTFOLIO LIABILITIES), (ii) debt liabilities (DEBT LIABILITIES), and (iii) foreign direct investment liabilities (FDI LIABILITIES). When looking explicitly at de facto financial integration, we find that foreign direct investment liabilities reinforce banking stability, while more volatile debt inflows raise the probability of a banking crisis, consistently with the evidence discussed by Joyce (2011) on a smaller sample of emerging markets.

Finally, in the last four columns we control for the possible influence of different aspects of the macroeconomic and institutional setting on banking sector stability. We find that the two variables which measure to what extent the institutional and economic environment is business friendly (COUNTRY RISK and SOUND MONEY) are negatively correlated with the likelihood of a banking crisis. This suggests that the rule of law, limited corruption and access to sound money are elements which mitigate the vulnerability of the banking system to systemic crises. By contrast, the presence of an institutionalized democratic regime, measured alternatively by a continuous index (POLITY) or by a dummy identifying democracies and autocracies (DEMOCRACY), is not correlated with a higher probability of banking crises, as suggested, instead, by Lipscy (2011).

\section{Conclusions}

The role of the Fund in past systemic banking crises has been extensively debated and the global financial crisis has further stimulated the discussion about the on-going IMF reform process, making the development of an enhanced crisis prevention toolkit a priority. In theory,

\footnotetext{
${ }^{17}$ Abiad et al. (2008) build a database of financial reforms which covers 91 economies over the period 1973-2005. Financial policy changes are recorded along seven different dimensions: credit controls and reserve requirements, interest rate controls, entry barriers, state ownership, policies on securities markets, banking regulations, and restrictions on the capital account. Liberalization scores for each category are combined in a graded index that is normalized between zero and one. This is the index used in the regressions and it has the advantage of being a continuous measure, rather than a 0/1 dummy for financially liberalized countries.
} 
IMF lending may influence the likelihood of systemic banking crises through a plethora of contrasting effects, related to liquidity support, moral hazard, and bad and good signaling. Hence, whether and how IMF involvement affects the probability of a systemic banking crisis remains an empirical question.

In this paper we contribute to this debate, estimating the effect of IMF-supported programs on the probability of banking crises in a large sample of developing countries. Our empirical results indicate that the standard probit estimates are biased by a reverse causality going from a higher probability of a banking crisis to a more likely intervention by the Fund. In other words, it is financial fragility which may lead to the Fund's intervention in the country, rather than the other way round. When we take into account the endogeneity of the IMF's presence in a country, our results consistently show that IMF lending programs are actually associated with a lower probability of banking crises occurring in future years. This finding suggests that the bad signals and moral hazard effects, if present, are offset by the credit availability provided the IMF-supported program.

We also find that the crisis prevention role of the Fund is connected to the macroeconomic policies and financial reforms which come with the loan and to a direct liquidity support effect. In fact, other things being equal, the likelihood of a banking crisis is lower for borrowers which are compliant with IMF conditionalities than for the non-compliant ones. In addition, we find that the negative association between IMF-supported programs and the probability of banking crises is significant only when the loan is sufficiently large. This result is consistent with the benefit of the IMF intervention acting through liquidity support.

We think that our analysis could be extended along two main lines of research. Ideally, one would be interested in analyzing how IMF intervention could affect banking sector stability through the promotion of financial sector reforms. Unfortunately, data availability so far has not made it possible to build a large panel data set. As a second-best option, the role of conditionalities could be analyzed by focusing on a measure of compliance with financial sector conditionality, which could be a better proxy of the capacity of the Fund to drive the reforms of the financial sector (Giustiniani and Kronenberg, 2005).

Second, one could focus not only on the effect of the IMF intervention on the likelihood of a banking crisis, but also on its costs. The data set compiled by Laeven and Valencia (2012) would make it possible to quantify the costs of a crisis in terms of liquidity support and output loss, measured as the cumulative sum of the differences between actual and trend real GDP, expressed as a percentage of trend real GDP, in the three-year period after the crisis.

\section{REFERENCES}

Abbas, S. M. A., Belhocine, N., El-Ganainy, A. A. and Horton, M. A. (2011). Historical patterns and dynamics of public debt - evidence from a new database. IMF Economic Review, 59 (4), 717-742.

ABIAD, A. and MODY, A. (2005). Financial reform: What shakes it? What shapes it? American Economic Review, 95 (1), 66-88. 
-, Tressel, T. and Detragiache, E. (2008). A New Database of Financial Reforms. IMF Working Papers 08/266, International Monetary Fund.

Aizenman, J. and Noy, I. (2012). Macroeconomic Adjustment and the History of Crises in Open Economies. NBER Working Papers 18527, National Bureau of Economic Research, Inc.

BARnebeck ANDERSEN, T., HARR, T. and TARP, F. (2006). On US politics and IMF lending. European Economic Review, 50 (7), 1843-1862.

BARRO, R. J. and LEE, J.-W. (2005). IMF programs: Who is chosen and what are the effects? Journal of Monetary Economics, 52 (7), 1245-1269.

Beck, T., Demirguc-Kunt, A. and LeVIne, R. (2006). Bank concentration, competition, and crises: First results. Journal of Banking Eamp; Finance, 30 (5), 1581-1603.

BIRD, G. (2007). The IMF: A bird's eye view of its role and operations. Journal of Economic Surveys, 21 (4), 683-745.

- and Rowlands, D. (2002). Do imf programmes have a catalytic effect on other international capital flows? Oxford Development Studies, 30 (3), 229-249.

- and - (2008). Catalysing private capital flows and IMF programs: some remaining questions. Journal of Economic Policy Reform, 11 (1), 37-43.

- and - (2009). The IMF's role in mobilizing private capital flows: are there grounds for catalytic conversion? Applied Economics Letters, 16 (17), 1705-1708.

Bordo, M. D. and JAMES, H. (2000). The International Monetary Fund: Its Present Role in Historical Perspective. NBER Working Papers 7724, National Bureau of Economic Research.

Chapman, T., FAnG, S., LI, X. and StOne, R. W. (2012). Mixed signals: crisis lending and capital markets, mimeo, University of Rochester.

Cheibub, J., Gandhi, J. and VReeland, J. (2010). Democracy and dictatorship revisited. Public Choice, 143 (1), 67-101.

CHINN, M. D. and ITO, H. (2010). A new measure of financial openness. Journal of Comparative Policy Analysis, 10 (3), 309-322.

CONWAY, P. (2006). The international monetary fund in a time of crisis: A review of Stanley Fischer's IMF essays from a time of crisis: The international financial system, stabilization, and development. Journal of Economic Literature, 44 (1), 115-144.

Copelovitch, M. S. (2010a). The International Monetary Fund in the Global Economy. Cambridge: Cambridge University Press.

- (2010b). Master or servant? Common agency and the political economy of IMF lending. International Studies Quarterly, 54 (1), 49-77. 
Corsetti, G., Guimaraes, B. and Roubini, N. (2006). International lending of last resort and moral hazard: A model of IMF's catalytic finance. Journal of Monetary Economics, 53 (3), $441-471$.

CotTARelli, C. and Giannini, C. (2006). Bedfellows, hostages, or perfect strangers? Global capital markets and the catalytic effect of IMF crisis lending. In A. Mody and A. Rebucci (eds.), IMF Supported Programs - Recent Staff Research, International Monetary Fund, pp. 202227.

De HAAn, J. and SHeHzAD, C. T. (2009). Financial Reform and Banking Crises. CESifo Working Paper Series 2870, CESifo Group Munich.

Demirguc-Kunt, A. and Detragiache, E. (1998). The determinants of banking crises in developing and developed countries. IMF Staff Papers, 45 (1), 3.

- and - (2005). Cross-country empirical studies of systemic bank distress: A survey. National Institute Economic Review, 192 (1), 68-83.

-, KANE, E. J. and LAEVEn, L. (2008). Determinants of deposit-insurance adoption and design. Journal of Financial Intermediation, 17 (3), 407-438.

DREHER, A. (2004). Does the IMF cause moral hazard? A critical review of the evidence. International Finance 0402003, EconWPA.

— (2009). Imf conditionality: theory and evidence. Public Choice, 141 (1), 233-267.

- and Jensen, N. M. (2007). Independent actor or agent? An empirical analysis of the impact of the US interests on IMF conditions. Journal of Law and Economics, 50 (1), 105-124.

-, STURM, J.-E. and VReELAND, J. R. (2009). Global horse trading: IMF loans for votes in the United NationsSecurity Council. European Economic Review, 53 (7), 742-757.

- and WALter, S. (2010). Does the IMF help or hurt? The effect of IMF programs on the likelihood and outcome of currency crises. World Development, 38 (1), 1-18.

DutTAgupta, R. and CASHIN, P. (2011). Anatomy of banking crises in developing and emerging market countries. Journal of International Money and Finance, 30 (2), 354-376.

Eichengreen, B., Gupta, P. and Mody, A. (2008). Sudden stops and IMF-supported programs. In Financial Markets Volatility and Performance in Emerging Markets, NBER Chapters, National Bureau of Economic Research, Inc, pp. 219-266.

Feldstein, M. (1998). Refocusing the IMF. Foreign Affairs, 77 (2), 20-33.

FISCHER, S. (1999). On the Need for an International Lender of Last Resort. Journal of Economic Perspectives, 13 (4), 85-104.

Fratianni, M. (2003). The Fund and its critics. In M. Fratianni, P. Savona and K. John (eds.), Sustaining Global Growth and Development, Berlin: Ashgate, pp. ???-???? 
Giustiniani, A. and KronenberG, R. P. (2005). Financial Sector Conditionality: Is Tougher Better? IMF Working Papers 05/230, International Monetary Fund.

GOLDSTEIN, M. (2001). IMF structural conditionality: How much is too much? Tech. rep., Peterson Institute for International Economics.

GWartney, J., LaWson, R. and Hall, J. (2012). Economic Freedom of the World, vol. 2012 Annual Report. Fraser Institute.

Haggard, S. and Kaufman, R. R. (1995). The Political Economy of Democratic Transitions. Princeton, New Jersey: Princeton University Press.

HALDANE, A. (1999). Private sector involvement in financial crises: Analytics and public policy approaches. Bank of England Financial Stability Review, November, 184-202.

HANSEN, B. E. (2000). Sample splitting and threshold estimation. Econometrica, 68 (3), 575-604.

Hardy, D. C. and Pazarbasioglu, C. (1999). Determinants and leading indicators of banking crises: Further evidence. IMF Staff Papers, 46 (3), 1.

JEAnNe, O. and Wyplosz, C. (2003). The international lender of last resort. How large is large enough? In Managing Currency Crises in Emerging Markets, NBER Chapters, National Bureau of Economic Research, Inc, pp. 89-124.

- and Zettelmeyer, J. (2001). International bailouts, moral hazard and conditionality. Economic Policy, 16 (33), 407-432.

JORRA, M. (2012). The effect of IMF lending on the probability of sovereign debt crises. Journal of International Money and Finance, 31 (4), 709-725.

JOYCE, J. (2011). Financial globalization and banking crises in emerging markets. Open Economies Review, 22 (5), 875-895.

— and RAZO-GARCIA, R. (2011). Reserves, quotas and the demand for international liquidity. The Review of International Organizations, 6 (3), 393-413.

KAMINSKY, G. L. and ReinhaRT, C. M. (1999). The twin crises: The causes of banking and balance-of-payments problems. American Economic Review, 89 (3), 473-500.

KILBY, C. (2009a). Donor influence in international financial institutions: Deciphering what alignment measures measure. Tech. Rep. 8, Villanova School of Business Department of Economics and Statistics.

- (2009b). The political economy of conditionality: An empirical analysis of World Bank loan disbursements. Journal of Development Economics, 89 (1), 310-329.

KLOMP, J. (2010). Causes of banking crises revisited. The North American Journal of Economics and Finance, 21 (1), 72-87. 
Laeven, L. and Valencia, F. (2008). Systemic Banking Crises: A New Database. IMF Working Papers 08/224, International Monetary Fund.

- and - (2012). Systemic Banking Crises Database: An Update. IMF Working Papers 12/163, International Monetary Fund.

Lane, P. and Milesi-Ferretti, G. (2007). The external wealth of nations mark ii: Revised and extended estimates of foreign assets and liabilities, 1970-2004. Journal of International Economics, 73 (2), 223-250.

LIPSCY, P. Y. (2011). Democracy and financial crisis, paper Presented at the Annual Meeting of the American Political Science Association.

Marshall, M. G., Gurr, T. R. and Jaggers, K. (2010). POLITY IV Project: Political Regime Characteristics and Transitions, 1800-2009. Center for Systemic Peace.

Miller, M. and ZHANG, L. (2000). Sovereign liquidity crises: The strategic case for a payments standstill. Economic Journal, 110 (460), 335-62.

Mody, A. and SARAVIA, D. (2006). Catalysing private capital flows: Do IMF programmes work as commitment devices? Economic Journal, 116 (513), 843-867.

MORRIS, S. and SHIN, H. S. (2006). Catalytic finance: When does it work? Journal of international Economics, 70 (1), 161-177.

NOY, I. (2004). Financial liberalization, prudential supervision, and the onset of banking crises. Emerging Markets Review, 5 (3), 341-359.

OAtley, T. and YACKEE, J. (2004). American interests and IMF lending. International Politics, $41(3), 415-29$.

Presbitero, A. F. and Zazzaro, A. (2012). IMF lending in times of crisis: Political influences and crisis prevention. World Development, 40 (10), 1944-1969.

Radelet, S. and SACHS, J. D. (1998). The East Asian Financial Crisis: Diagnosis, Remedies, Prospects. Brookings Papers on Economic Activity, 1998 (1), 1-74.

ReINHART, C. and RogOFF, K. (2008). Banking crises: an equal opportunity menace. NBER Working Papers 14587, National Bureau of Economic Research.

RODRIK, D. (2006). The social cost of foreign exchange reserves. International Economic Journal, 20 (3), 253-266.

RoGOFF, K. (1999). International institutions for reducing global financial instability. Journal of Economic Perspectives, 13 (4), 21-42.

SACHS, J. D. (2002). Resolving the debt crisis of low-income countries. Brookings Papers on Economic Activity, 2002 (1), 257-286. 
SARAVIA, D. (2010). Vulnerability, Crisis and Debt Maturity: do IMF Interventions Shorten the Length of Borrowing? Working Papers Central Bank of Chile 600, Central Bank of Chile.

Steinwand, M. C. and Stone, R. W. (2008). The International Monetary Fund: A review of the recent evidence. Review of International Organization, 3 (2), 123-149.

Stiglitz, J. E. (2002). Globalization and Its Discontents. New York: W. W. Norton \& Company.

StOcK, J. H. and YogO, M. (2005). Testing for weak instruments in linear IV regression. In D. W. Andrews and J. H. Stock (eds.), Identification and Inference for Econometric Models: Essays in Honor of Thomas Rothenberg, 5, Cambridge University Press, pp. 80-108.

Teorell, J., Charron, N., Samanni, M., Holmberg, S. and Rothstein, B. (2011). The Quality of Government Dataset. Tech. rep., University of Gothenburg: The Quality of Government Institute.

THACKer, S. C. (1999). The high politics of IMF lending. World Politics, 52 (10), 38-75.

VAN DER VEER, K. J. M. and DE JONG, E. (2013). IMF-supported programmes: Stimulating capital to non-defaulting countries. The World Economy, Forthcoming.

VAubeL, R. (1983). The moral hazard of imf lending. The World Economy, 6 (3), 291-304.

VON HAGEN, J. and Ho, T.-K. (2007). Money market pressure and the determinants of banking crises. Journal of Money, Credit and Banking, 39 (5), 1037-1066.

VREELAND, J. R. (1999). The IMF: Lender of last resort or scapegoat?, mimeo, Yale University.

- (2003). Why do governments and the IMF enter into agreements? Statistically selected casesinternational political science review. World Economy, 24 (3), 321-343.

ZETTELMEYer, J. (2000). Can official crisis lending be counterproductive in the short run? Economic Notes, 29 (1). 
Tables 


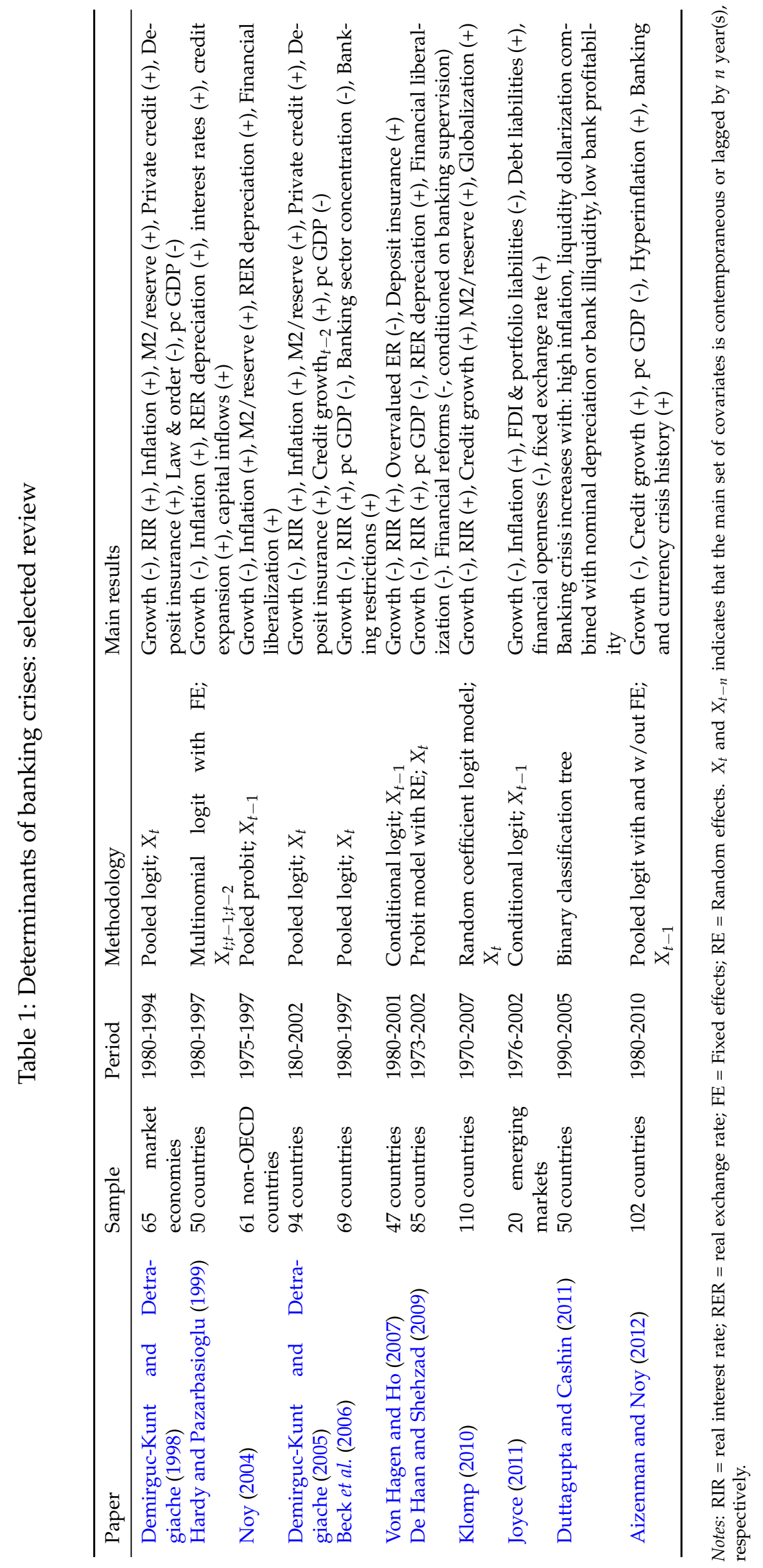


Table 2: Variables: definition and sources

\begin{tabular}{|c|c|c|}
\hline Variables & Definition & Sources \\
\hline BANKING CRISIS & $\begin{array}{l}\text { Dummy equal to one for country-year observations in which } \\
\text { there is a systemic banking crisis, and zero otherwise }\end{array}$ & $\begin{array}{l}\text { Laeven and Valencia } \\
\text { (2012) }\end{array}$ \\
\hline IMF ARRANGEMENT $_{t-1, t-5}$ & $\begin{array}{l}\text { Dummy equal to one for countries which signed an IMF loan } \\
\text { agreement in the previous five-year period, and zero otherwise. }\end{array}$ & IMF historical data set \\
\hline IMF LOAN/QUOTA $_{t-1, t-5}$ & $\begin{array}{l}\text { Logarithm of } 1+\text { the amount approved, as a share of the country } \\
\text { quota, by the IMF arrangement signed in the previous five-year } \\
\text { period. The variable is set to zero if the country has not signed } \\
\text { any agreement in the previous five-year period. In case of multi- } \\
\text { ple agreements, we take the sum of the loan-to-quota ratios }\end{array}$ & IMF historical data set \\
\hline NON-COMPLIANCE $_{t-1, t-5}$ & $\begin{array}{l}\text { Dummy equal to } 1 \text { if the country was compliant with its IMF } \\
\text { program in the previous } 5 \text { years. A country is coded as com- } \\
\text { pliant when at most } 25 \% \text { of the amount agreed under an IMF } \\
\text { arrangement remained undrawn at program expiration and as } \\
\text { zero otherwise }\end{array}$ & Dreher and Walter (2010) \\
\hline PROXIMITY_G7 $t-6, t-10$ & $\begin{array}{l}\text { Average alignment score, measured as the share of alignment } \\
\text { votes with G7 countries on regular UNGA votes between } t-6 \\
\text { and } t-10\end{array}$ & Kilby (2009a) \\
\hline MOVEMENT_G7 $t-6, t-10$ & $\begin{array}{l}\text { Change in the average alignment score with G7 countries be- } \\
\text { tween } t-6 \text { and } t-10\end{array}$ & Kilby (2009a) \\
\hline GDP PC & Logarithm of real GDP per capita, in constant UDS & $\begin{array}{l}\text { World Development In- } \\
\text { dicators }\end{array}$ \\
\hline GDP GROWTH & Annual growth rate of real GDP & $\begin{array}{l}\text { World Development In- } \\
\text { dicators }\end{array}$ \\
\hline PUBLIC DEBT & Total public debt (\% of GDP) & Abbas et al. (2011) \\
\hline SHORT TERM DEBT & Short-term debt (\% of total external debt) & $\begin{array}{l}\text { World Development In- } \\
\text { dicators }\end{array}$ \\
\hline REAL INTEREST RATE & $\begin{array}{l}\text { Real interest rate as the nominal interest rate (according to data } \\
\text { availability, Treasury Bill rate, discount rate, or deposit rate) mi- } \\
\text { nus the GDP deflator. }\end{array}$ & $\begin{array}{l}\text { International Financial } \\
\text { Statistics and World } \\
\text { Development Indicators }\end{array}$ \\
\hline CREDIT GROWTH & $\begin{array}{l}\text { Change in domestic credit to private sector (\% of GDP) between } \\
t \text { and } t-1\end{array}$ & $\begin{array}{l}\text { World Development In- } \\
\text { dicators }\end{array}$ \\
\hline INFLATION & GDP deflator & $\begin{array}{l}\text { World Development In- } \\
\text { dicators }\end{array}$ \\
\hline DEPRECIATION & $\begin{array}{l}\text { Rate of change of the nominal official exchange rate (for the US } \\
\text { this is the rate of change of the nominal effective exchange rate) }\end{array}$ & $\begin{array}{l}\text { World Development In- } \\
\text { dicators }\end{array}$ \\
\hline FINANCIAL OPENNESS & The Chinn-Ito de jure measure of financial openness & Chinn and Ito (2010) \\
\hline M2/RESERVE & Money and quasi money (M2) to total reserves ratio & $\begin{array}{l}\text { World Development In- } \\
\text { dicators }\end{array}$ \\
\hline COUNTRY RISK & $\begin{array}{l}\text { The Composite Index published by the International Country } \\
\text { Risk Guide (ICRG) }\end{array}$ & The PRS Group \\
\hline SOUND MONEY & $\begin{array}{l}\text { An index consisting of the following indicators: (i) Average an- } \\
\text { nual growth of the money supply in the last five years minus } \\
\text { average, (ii) annual growth of real GDP in the last ten years, (iii) } \\
\text { Standard inflation variability in the last five years, (iv) Recent } \\
\text { inflation rate, and (v) Freedom to own foreign currency bank ac- } \\
\text { counts domestically and abroad }\end{array}$ & $\begin{array}{l}\text { Fraser Institute, Gwart- } \\
\text { ney et al. (2012), and Teo- } \\
\text { rell et al. (2011) }\end{array}$ \\
\hline POLITY & $\begin{array}{l}\text { Polity score, based on six measures that record key qualities of } \\
\text { executive recruitment, constraints on executive authority, and } \\
\text { political competition. The index is part of the Polity IV project } \\
\text { and ranges from - } 10 \text { (hereditary monarchy) to }+10 \text { (consolidated } \\
\text { democracy). }\end{array}$ & $\begin{array}{l}\text { Marshall et al. (2010) and } \\
\text { Teorell et al. (2011) }\end{array}$ \\
\hline DEMOCRACY & Dummy variable coded 1 if the regime qualifies as democratic & Cheibub et al. (2010) \\
\hline CURRENCY_CRISIS & $\begin{array}{l}\text { Dummy equal to one for country-year observations in which } \\
\text { there is a currency crisis, and zero otherwise. }\end{array}$ & $\begin{array}{l}\text { Laeven and Valencia } \\
\text { (2012) }\end{array}$ \\
\hline BANK_CRISES $_{t-1, t-10}$ & $\begin{array}{l}\text { Dummy equal to one for country-year observations in which } \\
\text { there is at least a systemic banking crisis between } t-1 \text { and } t-10 \\
\text {, and zero otherwise. }\end{array}$ & $\begin{array}{l}\text { Laeven and Valencia } \\
\text { (2012) }\end{array}$ \\
\hline DEPOSIT INSURANCE & $\begin{array}{l}\text { Dummy equal to one for countries that adopted explicit deposit } \\
\text { insurance systems in year } t \text { and zero otherwise }\end{array}$ & $\begin{array}{l}\text { Demirguc-Kunt et al. } \\
\text { (2008) }\end{array}$ \\
\hline FINANCIAL REFORMS & $\begin{array}{l}\text { An index of financial liberalization, based on eight dimensions } \\
\text { and scaled between } 0 \text { (fully repressed) and } 1 \text { (fully liberalized) }\end{array}$ & Abiad et al. (2008) \\
\hline PORTFOLIO LIABILITIES & Portfolio equity liabilities (\% of GDP) & $\begin{array}{l}\text { Lane and Milesi-Ferretti } \\
\text { (2007, updated data set) }\end{array}$ \\
\hline DEBT LIABILITIES & Debt liabilities (\% of GDP) & $\begin{array}{l}\text { Lane and Milesi-Ferretti } \\
\text { (2007, updated data set) }\end{array}$ \\
\hline FDI LIABILITIES & Foreign direct investment liabilities ( $\%$ of GDP) & $\begin{array}{l}\text { Lane and Milesi-Ferretti } \\
\text { (2007, updated data set) }\end{array}$ \\
\hline
\end{tabular}


Table 3: IMF lending arrangements and banking crises

\begin{tabular}{|c|c|c|c|c|c|}
\hline \multirow[b]{3}{*}{ Whole sample } & \multicolumn{2}{|c|}{ No program } & \multicolumn{2}{|c|}{ IMF program agreed } & \multirow{2}{*}{$\begin{array}{l}\text { T-test } \\
\text { on means }\end{array}$} \\
\hline & \multirow[t]{2}{*}{ Obs. } & \multirow[t]{2}{*}{$\%$} & \multirow[t]{2}{*}{ Obs. } & \multirow[t]{2}{*}{$\%$} & \\
\hline & & & & & \\
\hline Tranquil year & 2,025 & 97.73 & 432 & 94.95 & \\
\hline Crisis year & 47 & 2.27 & 23 & 5.05 & $0.001^{* * *}$ \\
\hline Total & 2,072 & 100.00 & 455 & 100.00 & \\
\hline \multicolumn{6}{|c|}{ Middle-income countries } \\
\hline Tranquil year & 1,410 & 97.65 & 259 & 94.53 & \\
\hline Crisis year & 34 & 2.35 & 15 & 5.47 & $0.004^{* * *}$ \\
\hline Total & 1,444 & 100.00 & 274 & 100.00 & \\
\hline \multicolumn{6}{|c|}{ Low-income countries } \\
\hline Tranquil year & 615 & 97.93 & 173 & 95.58 & \\
\hline Crisis year & 13 & 2.07 & 8 & 4.42 & $0.080^{*}$ \\
\hline Total & 628 & 100.00 & 181 & 100.00 & \\
\hline
\end{tabular}

Notes: Statistics based on the sample used in the baseline regressions. The last column reports the p-values of the mean comparison test on the probability of systemic banking crisis in country-year observations in which an IMF program has been agreed or not. 
Table 4: Baseline regressions: IMF lending dummy

\begin{tabular}{|c|c|c|c|c|c|c|}
\hline \multirow[t]{2}{*}{ Dep Var: Prob(BANKING CRISIS) } & \multicolumn{3}{|c|}{ Whole sample } & \multirow{2}{*}{$\begin{array}{c}(4) \\
\text { Probit }\end{array}$} & \multirow{2}{*}{$\begin{array}{c}(5) \\
\text { pre-2007 } \\
\text { IVprobit }\end{array}$} & \multirow{2}{*}{$\begin{array}{c}(6) \\
\text { 2SLS }\end{array}$} \\
\hline & Probit & IVprobit & 2SLS & & & \\
\hline IMF ARRANGEMENT $_{t-1, t-5}$ & $\begin{array}{c}0.020 \\
{[0.127]}\end{array}$ & $\begin{array}{c}-1.086^{* * *} \\
{[0.404]}\end{array}$ & $\begin{array}{c}-0.067^{* *} \\
{[0.028]}\end{array}$ & $\begin{array}{c}0.068 \\
{[0.138]}\end{array}$ & $\begin{array}{l}-1.432^{* * *} \\
{[0.327]}\end{array}$ & $\begin{array}{l}-0.100^{* * *} \\
{[0.035]}\end{array}$ \\
\hline $\mathrm{GDP}_{P} \mathrm{PC}_{t-1}$ & $\begin{array}{c}-0.014 \\
{[0.052]}\end{array}$ & $\begin{array}{l}-0.107 \\
{[0.067]}\end{array}$ & $\begin{array}{l}-0.007^{*} \\
{[0.005]}\end{array}$ & $\begin{array}{c}-0.001 \\
{[0.057]}\end{array}$ & $\begin{array}{c}-0.109 \\
{[0.071]}\end{array}$ & $\begin{array}{l}-0.008 \\
{[0.006]}\end{array}$ \\
\hline GDP_GROWTH $_{t-1}$ & $\begin{array}{c}-0.429 \\
{[0.840]}\end{array}$ & $\begin{array}{c}-0.559 \\
{[0.877]}\end{array}$ & $\begin{array}{c}-0.017 \\
{[0.062]}\end{array}$ & $\begin{array}{l}-1.116 \\
{[0.865]}\end{array}$ & $\begin{array}{c}-0.734 \\
{[0.864]}\end{array}$ & $\begin{array}{c}-0.037 \\
{[0.071]}\end{array}$ \\
\hline PUBLIC_DEBT $_{t-1}$ & $\begin{array}{c}0.075 \\
{[0.103]}\end{array}$ & $\begin{array}{c}0.249^{*} \\
{[0.128]}\end{array}$ & $\begin{array}{c}0.014 \\
{[0.010]}\end{array}$ & $\begin{array}{c}0.112 \\
{[0.106]}\end{array}$ & $\begin{array}{c}0.392^{* * *} \\
{[0.129]}\end{array}$ & $\begin{array}{l}0.027^{* *} \\
{[0.014]}\end{array}$ \\
\hline SHORT_TERM_DEBT $_{t-1}$ & $\begin{array}{c}1.344^{* * *} \\
{[0.371]}\end{array}$ & $\begin{array}{l}1.066^{* *} \\
{[0.434]}\end{array}$ & $\begin{array}{l}0.085^{* *} \\
{[0.035]}\end{array}$ & $\begin{array}{c}1.201^{* * *} \\
{[0.453]}\end{array}$ & $\begin{array}{c}0.701 \\
{[0.549]}\end{array}$ & $\begin{array}{c}0.066 \\
{[0.049]}\end{array}$ \\
\hline REAL_INTEREST_RATE ${ }_{t-1}$ & $\begin{array}{l}0.252^{* *} \\
{[0.124]}\end{array}$ & $\begin{array}{l}0.564^{* *} \\
{[0.225]}\end{array}$ & $\begin{array}{l}0.047^{* *} \\
{[0.023]}\end{array}$ & $\begin{array}{c}0.217^{*} \\
{[0.124]}\end{array}$ & $\begin{array}{c}0.599^{* * *} \\
{[0.233]}\end{array}$ & $\begin{array}{l}0.054^{* *} \\
{[0.026]}\end{array}$ \\
\hline CREDIT_GROWTH $_{t-1}$ & $\begin{array}{c}0.002 \\
{[0.001]}\end{array}$ & $\begin{array}{c}0.001 \\
{[0.001]}\end{array}$ & $\begin{array}{c}0.000 \\
{[0.000]}\end{array}$ & $\begin{array}{c}0.001 \\
{[0.001]}\end{array}$ & $\begin{array}{c}0.000 \\
{[0.001]}\end{array}$ & $\begin{array}{c}0.000 \\
{[0.000]}\end{array}$ \\
\hline INFLATION $_{t-1}$ & $\begin{array}{c}0.136 \\
{[0.184]}\end{array}$ & $\begin{array}{c}0.447^{*} \\
{[0.235]}\end{array}$ & $\begin{array}{c}0.027 \\
{[0.023]}\end{array}$ & $\begin{array}{c}0.060 \\
{[0.218]}\end{array}$ & $\begin{array}{c}0.465^{*} \\
{[0.242]}\end{array}$ & $\begin{array}{c}0.031 \\
{[0.026]}\end{array}$ \\
\hline DEPRECIATION $_{t-1}$ & $\begin{array}{c}0.130 \\
{[0.151]}\end{array}$ & $\begin{array}{c}0.119 \\
{[0.130]}\end{array}$ & $\begin{array}{l}0.024^{* *} \\
{[0.010]}\end{array}$ & $\begin{array}{c}0.167 \\
{[0.192]}\end{array}$ & $\begin{array}{c}0.127 \\
{[0.144]}\end{array}$ & $\begin{array}{c}0.026^{* * *} \\
{[0.010]}\end{array}$ \\
\hline FINANCIAL_OPENNESS $_{t-1}$ & $\begin{array}{l}-0.042 \\
{[0.040]}\end{array}$ & $\begin{array}{l}-0.016 \\
{[0.045]}\end{array}$ & $\begin{array}{l}-0.001 \\
{[0.003]}\end{array}$ & $\begin{array}{l}-0.035 \\
{[0.044]}\end{array}$ & $\begin{array}{c}-0.007 \\
{[0.050]}\end{array}$ & $\begin{array}{l}-0.000 \\
{[0.004]}\end{array}$ \\
\hline $\mathrm{M} 2 / \operatorname{RESERVE}_{t-1}$ & $\begin{array}{c}0.652^{* * * *} \\
{[0.216]}\end{array}$ & $\begin{array}{c}0.476 \\
{[0.326]}\end{array}$ & $\begin{array}{c}0.093 \\
{[0.059]}\end{array}$ & $\begin{array}{c}0.618^{* * *} \\
{[0.209]}\end{array}$ & $\begin{array}{c}0.333 \\
{[0.349]}\end{array}$ & $\begin{array}{c}0.088 \\
{[0.063]}\end{array}$ \\
\hline Constant & $\begin{array}{c}-2.177^{* * *} \\
{[0.367]}\end{array}$ & $\begin{array}{l}-0.711 \\
{[0.741]}\end{array}$ & $\begin{array}{l}0.086^{* *} \\
{[0.038]}\end{array}$ & $\begin{array}{c}-2.253^{* * * *} \\
{[0.405]}\end{array}$ & $\begin{array}{l}-0.254 \\
{[0.713]}\end{array}$ & $\begin{array}{l}0.106^{* *} \\
{[0.046]}\end{array}$ \\
\hline \multicolumn{7}{|l|}{ First-stage coefficients } \\
\hline PROXIMITY_G7 $t-6, t-10$ & & $\begin{array}{l}1.171^{* * *} \\
{[0.266]}\end{array}$ & $\begin{array}{c}1.188^{* * *} \\
{[0.263]}\end{array}$ & & $\begin{array}{c}1.091^{* * *} \\
{[0.273]}\end{array}$ & $\begin{array}{c}1.109^{* * *} \\
{[0.276]}\end{array}$ \\
\hline MOVEMENT_G7 $t-6, t-10$ & & $\begin{array}{c}1.831^{* * *} \\
{[0.512]}\end{array}$ & $\begin{array}{c}1.732^{* * *} \\
{[0.537]}\end{array}$ & & $\begin{array}{c}1.720^{* * *} \\
{[0.491]}\end{array}$ & $\begin{array}{c}1.622^{* * *} \\
{[0.553]}\end{array}$ \\
\hline $\begin{array}{l}\text { Observations } \\
\text { Wald test of exogeneity (p-value) }\end{array}$ & 2,527 & $\begin{array}{l}2,527 \\
0,019\end{array}$ & 2,527 & 2,169 & $\begin{array}{l}2,169 \\
0.001\end{array}$ & 2,169 \\
\hline K-P weak identification (F-test) & & & 21.276 & & & 17.872 \\
\hline K-P underidentification ( $\mathrm{p}$-value) & & & 0.000 & & & 0.000 \\
\hline Overidentification tets (p-value) & & & 0.131 & & & 0.292 \\
\hline
\end{tabular}

Notes: The table reports the regression coefficients and, in brackets, the associated clustered (at country level) standard errors. ${ }^{*}$ significant at $10 \%$; ${ }^{* *}$ significant at $5 \%$; ${ }^{* *}$ significant at $1 \%$. At the bottom of the table we report some diagnostic tests. For the IV probit we report the p-value of the Wald test for the null hypothesis of no endogeneity. For the 2SLS we report the pvalue of: 1) the Kleibergen-Paap rk Wald F-statistic testing for weak identification; 2) the Kleibergen-Paap rk LM-statistic testing the null hypothesis that the excluded instruments are not correlated with the endogenous regressor; and 3) the Sargan test of overidentifying restrictions, testing the null hypothesis that the excluded instruments are not correlated with the error term (i.e. they are valid instruments). 
Table 5: Baseline regressions: IMF loan amount

\begin{tabular}{|c|c|c|c|c|c|c|}
\hline \multirow[t]{2}{*}{ Dep Var: Prob(BANKING CRISIS) } & \multicolumn{3}{|c|}{ Whole sample } & \multicolumn{3}{|c|}{$\begin{array}{c}(5) \\
\text { pre-2007 }\end{array}$} \\
\hline & Probit & IVprobit & 2SLS & Probit & IVprobit & 2SLS \\
\hline IMF LOAN/QUOTA $_{t-1, t-5}$ & $\begin{array}{c}0.170 \\
{[0.110]}\end{array}$ & $\begin{array}{l}-1.157^{* * *} \\
{[0.409]}\end{array}$ & $\begin{array}{c}-0.073^{* *} \\
{[0.034]}\end{array}$ & $\begin{array}{c}0.218^{*} \\
{[0.120]}\end{array}$ & $\begin{array}{c}-1.521^{* * *} \\
{[0.322]}\end{array}$ & $\begin{array}{c}-0.111^{* *} \\
{[0.044]}\end{array}$ \\
\hline GDP_PC $_{t-1}$ & $\begin{array}{l}-0.021 \\
{[0.048]}\end{array}$ & $\begin{array}{l}-0.025 \\
{[0.062]}\end{array}$ & $\begin{array}{l}-0.002 \\
{[0.004]}\end{array}$ & $\begin{array}{l}-0.013 \\
{[0.052]}\end{array}$ & $\begin{array}{l}-0.019 \\
{[0.068]}\end{array}$ & $\begin{array}{l}-0.002 \\
{[0.006]}\end{array}$ \\
\hline GDP_GROWTH $_{t-1}$ & $\begin{array}{l}-0.248 \\
{[0.842]}\end{array}$ & $\begin{array}{l}-1.196 \\
{[0.883]}\end{array}$ & $\begin{array}{l}-0.063 \\
{[0.068]}\end{array}$ & $\begin{array}{l}-0.941 \\
{[0.875]}\end{array}$ & $\begin{array}{c}-1.488^{* *} \\
{[0.747]}\end{array}$ & $\begin{array}{l}-0.103 \\
{[0.073]}\end{array}$ \\
\hline PUBLIC_DEBT $_{t-1}$ & $\begin{array}{c}0.055 \\
{[0.107]}\end{array}$ & $\begin{array}{l}0.298^{* *} \\
{[0.128]}\end{array}$ & $\begin{array}{c}0.017 \\
{[0.011]}\end{array}$ & $\begin{array}{c}0.094 \\
{[0.109]}\end{array}$ & $\begin{array}{c}0.422^{* * *} \\
{[0.119]}\end{array}$ & $\begin{array}{l}0.030^{* *} \\
{[0.015]}\end{array}$ \\
\hline SHORT_TERM_DEBT $_{t-1}$ & $\begin{array}{l}1.397^{* * *} \\
{[0.374]}\end{array}$ & $\begin{array}{l}0.936^{* *} \\
{[0.422]}\end{array}$ & $\begin{array}{l}0.080^{* *} \\
{[0.035]}\end{array}$ & $\begin{array}{l}1.262^{* * * *} \\
{[0.454]}\end{array}$ & $\begin{array}{c}0.573 \\
{[0.504]}\end{array}$ & $\begin{array}{c}0.061 \\
{[0.049]}\end{array}$ \\
\hline REAL_INTEREST_RATE ${ }_{t-1}$ & $\begin{array}{l}0.216^{*} \\
{[0.116]}\end{array}$ & $\begin{array}{l}0.664^{* *} \\
{[0.286]}\end{array}$ & $\begin{array}{l}0.054^{*} \\
{[0.028]}\end{array}$ & $\begin{array}{c}0.179 \\
{[0.115]}\end{array}$ & $\begin{array}{l}0.732^{* *} \\
{[0.306]}\end{array}$ & $\begin{array}{l}0.066^{*} \\
{[0.034]}\end{array}$ \\
\hline CREDIT_GROWTH $_{t-1}$ & $\begin{array}{c}0.002 \\
{[0.001]}\end{array}$ & $\begin{array}{c}0.000 \\
{[0.001]}\end{array}$ & $\begin{array}{c}0.000 \\
{[0.000]}\end{array}$ & $\begin{array}{c}0.001 \\
{[0.001]}\end{array}$ & $\begin{array}{l}-0.000 \\
{[0.001]}\end{array}$ & $\begin{array}{c}0.000 \\
{[0.000]}\end{array}$ \\
\hline INFLATION $_{t-1}$ & $\begin{array}{c}0.110 \\
{[0.180]}\end{array}$ & $\begin{array}{l}0.514^{* *} \\
{[0.250]}\end{array}$ & $\begin{array}{c}0.031 \\
{[0.025]}\end{array}$ & $\begin{array}{c}0.037 \\
{[0.215]}\end{array}$ & $\begin{array}{l}0.568^{* * *} \\
{[0.261]}\end{array}$ & $\begin{array}{c}0.039 \\
{[0.030]}\end{array}$ \\
\hline DEPRECIATION $_{t-1}$ & $\begin{array}{c}0.123 \\
{[0.147]}\end{array}$ & $\begin{array}{c}0.148 \\
{[0.112]}\end{array}$ & $\begin{array}{c}0.026^{* * * *} \\
{[0.009]}\end{array}$ & $\begin{array}{c}0.155 \\
{[0.187]}\end{array}$ & $\begin{array}{c}0.154 \\
{[0.118]}\end{array}$ & $\begin{array}{l}0.029^{* * *} \\
{[0.009]}\end{array}$ \\
\hline FINANCIAL_OPENNESS $_{t-1}$ & $\begin{array}{l}-0.043 \\
{[0.040]}\end{array}$ & $\begin{array}{l}-0.032 \\
{[0.043]}\end{array}$ & $\begin{array}{l}-0.002 \\
{[0.003]}\end{array}$ & $\begin{array}{l}-0.034 \\
{[0.043]}\end{array}$ & $\begin{array}{l}-0.035 \\
{[0.047]}\end{array}$ & $\begin{array}{l}-0.002 \\
{[0.004]}\end{array}$ \\
\hline $\mathrm{M}_{2} / \operatorname{RESERVE}_{t-1}$ & $\begin{array}{c}0.647^{* * * *} \\
{[0.205]}\end{array}$ & $\begin{array}{c}0.560 \\
{[0.340]}\end{array}$ & $\begin{array}{l}0.100^{*} \\
{[0.061]}\end{array}$ & $\begin{array}{c}0.611^{* * *} \\
{[0.198]}\end{array}$ & $\begin{array}{c}0.446 \\
{[0.364]}\end{array}$ & $\begin{array}{c}0.099 \\
{[0.067]}\end{array}$ \\
\hline Constant & $\begin{array}{c}-2.192^{* * *} \\
{[0.331]}\end{array}$ & $\begin{array}{l}-1.316^{* *} \\
{[0.599]}\end{array}$ & $\begin{array}{c}0.039 \\
{[0.032]}\end{array}$ & $\begin{array}{c}-2.233^{* * *} \\
{[0.365]}\end{array}$ & $\begin{array}{l}-0.915 \\
{[0.622]}\end{array}$ & $\begin{array}{c}0.047 \\
{[0.043]}\end{array}$ \\
\hline \multicolumn{7}{|l|}{ First-stage coefficients } \\
\hline PROXIMITY_G7 $t-6, t-10$ & & $\begin{array}{l}1.080^{* * *} \\
{[0.295]}\end{array}$ & $\begin{array}{l}1.101^{* * *} \\
{[0.292]}\end{array}$ & & $\begin{array}{l}0.963^{* * *} \\
{[0.265]}\end{array}$ & $\begin{array}{c}0.981^{* * *} \\
{[0.271]}\end{array}$ \\
\hline MOVEMENT_G7 $t-6, t-10$ & & $\begin{array}{c}1.986^{* * *} \\
{[0.476]}\end{array}$ & $\begin{array}{l}1.874^{* * * *} \\
{[0.513]}\end{array}$ & & $\begin{array}{l}1.813^{* * * *} \\
{[0.430]}\end{array}$ & $\begin{array}{l}1.728^{* * *} \\
{[0.497]}\end{array}$ \\
\hline Observations & 2,527 & 2,527 & 2,527 & 2,169 & 2,169 & 2,169 \\
\hline $\begin{array}{l}\text { Wald test of exogeneity (p-value) } \\
\text { K-P weak identification (F-test) }\end{array}$ & & 0.004 & 13.702 & & 0.000 & 12.599 \\
\hline K-P underidentification ( $p$-value) & & & 0.000 & & & 0.000 \\
\hline Overidentification tets (p-value) & & & 0.175 & & & 0.405 \\
\hline
\end{tabular}

Notes: The table reports the regression coefficients and, in brackets, the associated clustered (at country level) standard errors. ${ }^{*}$ significant at $10 \%$; ${ }^{* *}$ significant at $5 \%$; ${ }^{* *}$ significant at $1 \%$. At the bottom of the table we report some diagnostic tests. For the IV probit we report the p-value of the Wald test for the null hypothesis of no endogeneity. For the 2SLS we report the pvalue of: 1) the Kleibergen-Paap rk Wald F-statistic testing for weak identification; 2) the Kleibergen-Paap rk LM-statistic testing the null hypothesis that the excluded instruments are not correlated with the endogenous regressor; and 3) the Sargan test of overidentifying restrictions, testing the null hypothesis that the excluded instruments are not correlated with the error term (i.e. they are valid instruments). 
Table 6: Sample splits according to the size of the loan

\begin{tabular}{|c|c|c|c|c|c|c|}
\hline Dep Var: Prob(BANK CRISIS) & & n size (as & $\%$ of the & untry qu & at the $\mathrm{Fu}$ & \\
\hline & $\begin{array}{l}<40 \\
(1)\end{array}$ & $\begin{array}{c}>=40 \\
(2)\end{array}$ & $\begin{array}{l}<50 \\
(3)\end{array}$ & $\begin{array}{c}>=50 \\
(4)\end{array}$ & $\begin{array}{l}<60 \\
(5)\end{array}$ & $\begin{array}{c}>=60 \\
(6)\end{array}$ \\
\hline IMF ARRANGEMENT $_{t-1, t-5}$ & $\begin{array}{c}-0.784 \\
{[1.430]}\end{array}$ & $\begin{array}{c}-1.247^{* * *} \\
{[0.398]}\end{array}$ & $\begin{array}{c}-0.983 \\
{[1.225]}\end{array}$ & $\begin{array}{c}-1.225^{* * *} \\
{[0.408]}\end{array}$ & $\begin{array}{c}-0.870 \\
{[0.863]}\end{array}$ & $\begin{array}{c}-1.269^{* * *} \\
{[0.411]}\end{array}$ \\
\hline First-stage coefficients & & & & & & \\
\hline & $\begin{array}{l}0.861^{* *} \\
{[0.349]}\end{array}$ & $\begin{array}{l}1.082^{* * *} \\
{[0.279]}\end{array}$ & $\begin{array}{l}0.860^{* *} \\
{[0.368]}\end{array}$ & $\begin{array}{c}1.112^{* * *} \\
{[0.276]}\end{array}$ & $\begin{array}{c}1.137^{* * *} \\
{[0.326]}\end{array}$ & $\begin{array}{c}1.031^{* * *} \\
{[0.302]}\end{array}$ \\
\hline CHANGE_UNGA_ALIGNMENT_G7 $t-6, t-10$ & $\begin{array}{c}0.517 \\
{[0.855]}\end{array}$ & $\begin{array}{c}2.292^{* * * *} \\
{[0.559]}\end{array}$ & $\begin{array}{c}0.752 \\
{[0.849]}\end{array}$ & $\begin{array}{c}2.412^{* * * *} \\
{[0.567]}\end{array}$ & $\begin{array}{c}0.775 \\
{[0.814]}\end{array}$ & $\begin{array}{c}2.584^{* * *} \\
{[0.574]}\end{array}$ \\
\hline Observations & 1,292 & 2,305 & 1,382 & 2,215 & 1,496 & 2,101 \\
\hline Wald test of exogeneity (p-value) & 0.751 & 0.008 & 0.572 & 0.009 & 0.552 & 0.008 \\
\hline & $\begin{array}{l}<70 \\
(7)\end{array}$ & $\begin{array}{c}>=70 \\
(8)\end{array}$ & $\begin{array}{l}<80 \\
(9)\end{array}$ & $\begin{array}{c}>=80 \\
(10)\end{array}$ & $\begin{array}{l}<90 \\
(11)\end{array}$ & $\begin{array}{c}>=90 \\
(12)\end{array}$ \\
\hline IMF ARRANGEMENT $_{t-1, t-5}$ & $\begin{array}{c}-0.518 \\
{[0.882]}\end{array}$ & $\begin{array}{c}-1.249^{* * *} \\
{[0.410]}\end{array}$ & $\begin{array}{l}-0.826 \\
{[0.709]}\end{array}$ & $\begin{array}{c}-1.171^{* *} \\
{[0.472]}\end{array}$ & $\begin{array}{l}-1.088^{*} \\
{[0.564]}\end{array}$ & $\begin{array}{c}-1.154^{* *} \\
{[0.554]}\end{array}$ \\
\hline First-stage coefficients & & & & & & \\
\hline UNGA ALIGNMENT_G7 $t-6, t-10$ & $\begin{array}{c}1.205^{* * *} \\
{[0.299]}\end{array}$ & $\begin{array}{c}1.030^{* * *} \\
{[0.306]}\end{array}$ & $\begin{array}{c}1.292^{* * *} \\
{[0.304]}\end{array}$ & $\begin{array}{c}0.893^{* * *} \\
{[0.299]}\end{array}$ & $\begin{array}{l}1.305^{* * *} \\
{[0.297]}\end{array}$ & $\begin{array}{c}0.757^{* * *} \\
{[0.282]}\end{array}$ \\
\hline CHANGE_UNGA_ALIGNMENT_G7 $t-6, t-10$ & $\begin{array}{c}1.041 \\
{[0.816]}\end{array}$ & $\begin{array}{c}2.572^{* * *} \\
{[0.586]}\end{array}$ & $\begin{array}{c}1.250 \\
{[0.776]}\end{array}$ & $\begin{array}{c}2.655^{* * *} \\
{[0.578]}\end{array}$ & $\begin{array}{l}1.745^{* * *} \\
{[0.704]}\end{array}$ & $\begin{array}{c}2.434^{* * * *} \\
{[0.581]}\end{array}$ \\
\hline Observations & 1,632 & 1,965 & 1,753 & 1,844 & 1,891 & 1,706 \\
\hline Wald test of exogeneity (p-value) & 0.679 & 0.008 & 0.364 & 0.020 & 0.163 & 0.040 \\
\hline & $\begin{array}{c}<100 \\
(13)\end{array}$ & $\begin{array}{c}>=100 \\
(14)\end{array}$ & $\begin{array}{c}<110 \\
(15)\end{array}$ & $\begin{array}{c}>=110 \\
(16)\end{array}$ & $\begin{array}{c}<120 \\
(17)\end{array}$ & $\begin{array}{c}>=120 \\
(18)\end{array}$ \\
\hline IMF ARRANGEMENT $_{t-1, t-5}$ & $\begin{array}{l}-1.076^{*} \\
{[0.593]}\end{array}$ & $\begin{array}{c}-1.134^{* *} \\
{[0.535]}\end{array}$ & $\begin{array}{l}-1.081^{*} \\
{[0.593]}\end{array}$ & $\begin{array}{l}-1.047^{*} \\
{[0.573]}\end{array}$ & $\begin{array}{l}-1.117^{*} \\
{[0.587]}\end{array}$ & $\begin{array}{l}-1.023^{*} \\
{[0.572]}\end{array}$ \\
\hline First-stage coefficients & & & & & & \\
\hline UNGA ALIGNMENT_G7 $t-6, t-10$ & $\begin{array}{l}1.292^{* * *} \\
{[0.298]}\end{array}$ & $\begin{array}{c}0.769^{* * *} \\
{[0.272]}\end{array}$ & $\begin{array}{c}1.289 * * * \\
{[0.298]}\end{array}$ & $\begin{array}{c}0.763^{* * *} \\
{[0.273]}\end{array}$ & $\begin{array}{c}1.258^{* * *} \\
{[0.301]}\end{array}$ & $\begin{array}{c}0.812^{* * *} \\
{[0.275]}\end{array}$ \\
\hline CHANGE_UNGA_ALIGNMENT_G7 $t-6, t-10$ & $\begin{array}{l}1.562^{* *} \\
{[0.702]}\end{array}$ & $\begin{array}{c}2.590^{* * * *} \\
{[0.574]}\end{array}$ & $\begin{array}{l}1.534^{* *} \\
{[0.707]}\end{array}$ & $\begin{array}{c}2.706^{* * * *} \\
{[0.577]}\end{array}$ & $\begin{array}{l}1.622^{* * *} \\
{[0.692]}\end{array}$ & $\begin{array}{c}2.668^{* * *} \\
{[0.589]}\end{array}$ \\
\hline Observations & 1,914 & 1,683 & 1,960 & 1,637 & 1,998 & 1,599 \\
\hline Wald test of exogeneity (p-value) & 0.195 & 0.032 & 0.164 & 0.058 & 0.156 & 0.056 \\
\hline
\end{tabular}

Notes: The table reports the regression coefficients and, in brackets, the associated clustered (at country level) standard errors. * significant at 10\%; ${ }^{* *}$ significant at 5\%; ${ }^{* * *}$ significant at $1 \%$. All regressions include the standard set of control variables, as in the baseline specification of Table 4, not reported for reasons of space. At the bottom of the table we report the p-value of the Wald test for the null hypothesis of no endogeneity. 
Table 7: The role of compliance with conditionality

\begin{tabular}{|c|c|c|c|c|c|c|}
\hline \multirow[t]{2}{*}{ Dep Var: Prob(BANKING CRISIS) } & \multicolumn{3}{|c|}{ Whole sample } & \multicolumn{3}{|c|}{$\begin{array}{c}(5) \\
\text { pre-2007 }\end{array}$} \\
\hline & Probit & IVprobit & 2SLS & Probit & IVprobit & 2SLS \\
\hline IMF ARRANGEMENT $_{t-1, t-5}$ & $\begin{array}{l}-0.141 \\
{[0.152]}\end{array}$ & $\begin{array}{c}-2.368^{* * *} \\
{[0.541]}\end{array}$ & $\begin{array}{c}-0.189^{* *} \\
{[0.095]}\end{array}$ & $\begin{array}{l}-0.059 \\
{[0.166]}\end{array}$ & $\begin{array}{c}-2.805^{* * *} \\
{[0.344]}\end{array}$ & $\begin{array}{c}-0.307^{* *} \\
{[0.149]}\end{array}$ \\
\hline NON_COMPLIANCE $E_{t-1, t-5}$ & $\begin{array}{l}0.214^{*} \\
{[0.129]}\end{array}$ & $\begin{array}{l}1.636^{* * * *} \\
{[0.350]}\end{array}$ & $\begin{array}{l}0.131^{* *} \\
{[0.064]}\end{array}$ & $\begin{array}{c}0.161 \\
{[0.141]}\end{array}$ & $\begin{array}{c}2.005^{* * *} \\
{[0.255]}\end{array}$ & $\begin{array}{l}0.221^{* *} \\
{[0.105]}\end{array}$ \\
\hline GDP $P C_{t-1}$ & $\begin{array}{l}-0.016 \\
{[0.052]}\end{array}$ & $\begin{array}{l}-0.153^{* *} \\
{[0.062]}\end{array}$ & $\begin{array}{l}-0.013^{*} \\
{[0.007]}\end{array}$ & $\begin{array}{c}-0.003 \\
{[0.057]}\end{array}$ & $\begin{array}{l}-0.143^{* *} \\
{[0.059]}\end{array}$ & $\begin{array}{l}-0.016 \\
{[0.010]}\end{array}$ \\
\hline GDP_GROWTH $_{t-1}$ & $\begin{array}{l}-0.439 \\
{[0.841]}\end{array}$ & $\begin{array}{l}-0.209 \\
{[0.727]}\end{array}$ & $\begin{array}{c}0.002 \\
{[0.066]}\end{array}$ & $\begin{array}{l}-1.095 \\
{[0.875]}\end{array}$ & $\begin{array}{c}0.229 \\
{[0.750]}\end{array}$ & $\begin{array}{c}0.041 \\
{[0.094]}\end{array}$ \\
\hline PUBLIC_DEBT $_{t-1}$ & $\begin{array}{c}0.078 \\
{[0.101]}\end{array}$ & $\begin{array}{c}0.308^{* * *} \\
{[0.109]}\end{array}$ & $\begin{array}{l}0.024^{*} \\
{[0.014]}\end{array}$ & $\begin{array}{c}0.115 \\
{[0.104]}\end{array}$ & $\begin{array}{c}0.418^{* * *} \\
{[0.112]}\end{array}$ & $\begin{array}{l}0.046^{*} \\
{[0.024]}\end{array}$ \\
\hline SHORT_TERM_DEBT $_{t-1}$ & $\begin{array}{c}1.343^{* * *} \\
{[0.371]}\end{array}$ & $\begin{array}{c}0.588 \\
{[0.479]}\end{array}$ & $\begin{array}{c}0.068^{*} \\
{[0.037]}\end{array}$ & $\begin{array}{l}1.184^{* * *} \\
{[0.457]}\end{array}$ & $\begin{array}{c}0.090 \\
{[0.480]}\end{array}$ & $\begin{array}{c}0.026 \\
{[0.058]}\end{array}$ \\
\hline REAL_INTEREST_RATE $t_{t-1}$ & $\begin{array}{l}0.245^{* *} \\
{[0.125]}\end{array}$ & $\begin{array}{l}0.477^{* *} \\
{[0.189]}\end{array}$ & $\begin{array}{c}0.051^{*} \\
{[0.026]}\end{array}$ & $\begin{array}{l}0.214^{*} \\
{[0.125]}\end{array}$ & $\begin{array}{l}0.459^{* *} \\
{[0.193]}\end{array}$ & $\begin{array}{l}0.063^{*} \\
{[0.034]}\end{array}$ \\
\hline CREDIT_GROWTH $_{t-1}$ & $\begin{array}{c}0.002 \\
{[0.001]}\end{array}$ & $\begin{array}{c}0.001 \\
{[0.001]}\end{array}$ & $\begin{array}{c}0.000 \\
{[0.000]}\end{array}$ & $\begin{array}{c}0.001 \\
{[0.001]}\end{array}$ & $\begin{array}{c}0.001 \\
{[0.001]}\end{array}$ & $\begin{array}{c}0.000 \\
{[0.000]}\end{array}$ \\
\hline INFLATION $_{t-1}$ & $\begin{array}{c}0.131 \\
{[0.183]}\end{array}$ & $\begin{array}{l}0.403^{* *} \\
{[0.205]}\end{array}$ & $\begin{array}{c}0.032 \\
{[0.028]}\end{array}$ & $\begin{array}{c}0.060 \\
{[0.216]}\end{array}$ & $\begin{array}{c}0.401^{*} \\
{[0.208]}\end{array}$ & $\begin{array}{c}0.043 \\
{[0.036]}\end{array}$ \\
\hline DEPRECIATION $_{t-1}$ & $\begin{array}{c}0.129 \\
{[0.149]}\end{array}$ & $\begin{array}{c}0.073 \\
{[0.101]}\end{array}$ & $\begin{array}{l}0.023^{* *} \\
{[0.010]}\end{array}$ & $\begin{array}{c}0.164 \\
{[0.189]}\end{array}$ & $\begin{array}{c}0.052 \\
{[0.100]}\end{array}$ & $\begin{array}{l}0.023^{* * *} \\
{[0.011]}\end{array}$ \\
\hline FINANCIAL_OPENNESS $_{t-1}$ & $\begin{array}{l}-0.044 \\
{[0.040]}\end{array}$ & $\begin{array}{l}-0.002 \\
{[0.045]}\end{array}$ & $\begin{array}{c}0.000 \\
{[0.004]}\end{array}$ & $\begin{array}{l}-0.036 \\
{[0.044]}\end{array}$ & $\begin{array}{c}0.001 \\
{[0.046]}\end{array}$ & $\begin{array}{c}0.000 \\
{[0.005]}\end{array}$ \\
\hline $\mathrm{M} / \mathrm{RESERVE}_{t-1}$ & $\begin{array}{c}0.640^{* * *} \\
{[0.212]}\end{array}$ & $\begin{array}{c}0.179 \\
{[0.301]}\end{array}$ & $\begin{array}{c}0.079 \\
{[0.059]}\end{array}$ & $\begin{array}{c}0.610^{* * *} \\
{[0.207]}\end{array}$ & $\begin{array}{c}0.030 \\
{[0.267]}\end{array}$ & $\begin{array}{c}0.068 \\
{[0.064]}\end{array}$ \\
\hline Constant & $\begin{array}{c}-2.180^{* * * *} \\
{[0.364]}\end{array}$ & $\begin{array}{c}0.058 \\
{[0.948]}\end{array}$ & $\begin{array}{l}0.129^{*} \\
{[0.066]}\end{array}$ & $\begin{array}{c}-2.248^{* * * *} \\
{[0.405]}\end{array}$ & $\begin{array}{c}0.394 \\
{[0.743]}\end{array}$ & $\begin{array}{l}0.165^{*} \\
{[0.089]}\end{array}$ \\
\hline \multicolumn{7}{|l|}{ First-stage coefficients } \\
\hline PROXIMITY_G7 $t-6, t-10$ & & $\begin{array}{l}0.447^{* *} \\
{[0.200]}\end{array}$ & $\begin{array}{l}0.471^{* *} \\
{[0.190]}\end{array}$ & & $\begin{array}{l}0.376^{* *} \\
{[0.178]}\end{array}$ & $\begin{array}{l}0.399 * * \\
{[0.181]}\end{array}$ \\
\hline MOVEMENT_G7 $t-6, t-10$ & & $\begin{array}{l}0.734^{* *} \\
{[0.303]}\end{array}$ & $\begin{array}{l}0.594^{*} \\
{[0.344]}\end{array}$ & & $\begin{array}{l}0.656^{* *} \\
{[0.267]}\end{array}$ & $\begin{array}{l}0.543^{*} \\
{[0.326]}\end{array}$ \\
\hline Observations & 2,527 & 2,527 & 2,527 & 2,169 & 2,169 & 2,169 \\
\hline Wald test of exogeneity (p-value) & & 0.031 & & & 0.003 & \\
\hline K-P weak identification (F-test) & & & 5.176 & & & 3.749 \\
\hline K-P underidentification ( $\mathrm{p}$-value) & & & 0.011 & & & 0.024 \\
\hline Overidentification tets (p-value) & & & 0.133 & & & 0.316 \\
\hline
\end{tabular}

Notes: The table reports the regression coefficients and, in brackets, the associated clustered (at country level) standard errors. ${ }^{*}$ significant at $10 \%$; ${ }^{* *}$ significant at $5 \%$; ${ }^{* *}$ significant at $1 \%$. At the bottom of the table we report some diagnostic tests. For the IV probit we report the p-value of the Wald test for the null hypothesis of no endogeneity. For the 2SLS we report the pvalue of: 1) the Kleibergen-Paap rk Wald F-statistic testing for weak identification; 2) the Kleibergen-Paap rk LM-statistic testing the null hypothesis that the excluded instruments are not correlated with the endogenous regressor; and 3) the Sargan test of overidentifying restrictions, testing the null hypothesis that the excluded instruments are not correlated with the error term (i.e. they are valid instruments). 
Table 8: Baseline regressions: disentangling between concessional and non-concessional lending

\begin{tabular}{|c|c|c|c|c|c|c|}
\hline \multirow[t]{2}{*}{ Dep Var: Prob(BANKING CRISIS) } & \multicolumn{3}{|c|}{$\begin{array}{c}(2) \\
\text { GRA }\end{array}$} & \multicolumn{3}{|c|}{ PRGT \& PRGF } \\
\hline & Probit & IVprobit & 2SLS & Probit & IVprobit & 2SLS \\
\hline IMF ARRANGEMENT $_{t-1, t-5}$ & $\begin{array}{c}0.084 \\
{[0.127]}\end{array}$ & $\begin{array}{c}-1.070 * * * \\
{[0.380]}\end{array}$ & $\begin{array}{c}-0.067^{* *} \\
{[0.028]}\end{array}$ & $\begin{array}{c}0.084 \\
{[0.145]}\end{array}$ & $\begin{array}{c}-1.310^{* * *} \\
{[0.414]}\end{array}$ & $\begin{array}{c}-0.076^{* *} \\
{[0.034]}\end{array}$ \\
\hline GDP_PC $_{t-1}$ & $\begin{array}{l}-0.009 \\
{[0.054]}\end{array}$ & $\begin{array}{l}-0.103 \\
{[0.067]}\end{array}$ & $\begin{array}{l}-0.007 \\
{[0.005]}\end{array}$ & $\begin{array}{l}-0.016 \\
{[0.064]}\end{array}$ & $\begin{array}{l}-0.161^{*} \\
{[0.085]}\end{array}$ & $\begin{array}{l}-0.010^{*} \\
{[0.006]}\end{array}$ \\
\hline GDP_GROWTH $_{t-1}$ & $\begin{array}{c}-0.248 \\
{[0.873]}\end{array}$ & $\begin{array}{l}-0.517 \\
{[0.908]}\end{array}$ & $\begin{array}{c}-0.012 \\
{[0.063]}\end{array}$ & $\begin{array}{c}-0.976 \\
{[0.991]}\end{array}$ & $\begin{array}{l}-0.679 \\
{[0.919]}\end{array}$ & $\begin{array}{l}-0.029 \\
{[0.061]}\end{array}$ \\
\hline PUBLIC_DEBT $t_{t-1}$ & $\begin{array}{l}-0.029 \\
{[0.123]}\end{array}$ & $\begin{array}{c}0.182 \\
{[0.164]}\end{array}$ & $\begin{array}{c}0.008 \\
{[0.012]}\end{array}$ & $\begin{array}{l}-0.000 \\
{[0.132]}\end{array}$ & $\begin{array}{l}0.240^{*} \\
{[0.139]}\end{array}$ & $\begin{array}{c}0.011 \\
{[0.011]}\end{array}$ \\
\hline SHORT_TERM_DEBT $_{t-1}$ & $\begin{array}{l}1.332^{* * *} \\
{[0.378]}\end{array}$ & $\begin{array}{l}1.086^{* *} \\
{[0.427]}\end{array}$ & $\begin{array}{l}0.087^{* *} \\
{[0.036]}\end{array}$ & $\begin{array}{c}1.293^{* * * *} \\
{[0.426]}\end{array}$ & $\begin{array}{l}0.964^{* *} \\
{[0.436]}\end{array}$ & $\begin{array}{l}0.069^{* *} \\
{[0.033]}\end{array}$ \\
\hline REAL_INTEREST_RATE ${ }_{t-1}$ & $\begin{array}{l}0.206^{*} \\
{[0.112]}\end{array}$ & $\begin{array}{l}0.539^{* *} \\
{[0.221]}\end{array}$ & $\begin{array}{l}0.043^{* *} \\
{[0.021]}\end{array}$ & $\begin{array}{c}0.224^{*} \\
{[0.116]}\end{array}$ & $\begin{array}{c}0.608^{* * *} \\
{[0.229]}\end{array}$ & $\begin{array}{l}0.046^{* *} \\
{[0.022]}\end{array}$ \\
\hline CREDIT_GROWTH $H_{t-1}$ & $\begin{array}{c}0.001 \\
{[0.001]}\end{array}$ & $\begin{array}{c}0.001 \\
{[0.001]}\end{array}$ & $\begin{array}{c}0.000 \\
{[0.000]}\end{array}$ & $\begin{array}{c}0.002 \\
{[0.001]}\end{array}$ & $\begin{array}{c}0.001 \\
{[0.001]}\end{array}$ & $\begin{array}{c}0.000 \\
{[0.000]}\end{array}$ \\
\hline INFLATION $_{t-1}$ & $\begin{array}{c}0.049 \\
{[0.224]}\end{array}$ & $\begin{array}{c}0.392 \\
{[0.252]}\end{array}$ & $\begin{array}{c}0.021 \\
{[0.021]}\end{array}$ & $\begin{array}{c}0.179 \\
{[0.125]}\end{array}$ & $\begin{array}{l}0.513^{* * *} \\
{[0.217]}\end{array}$ & $\begin{array}{c}0.028 \\
{[0.023]}\end{array}$ \\
\hline DEPRECIATION $_{t-1}$ & $\begin{array}{c}0.171 \\
{[0.196]}\end{array}$ & $\begin{array}{c}0.148 \\
{[0.166]}\end{array}$ & $\begin{array}{c}0.025^{* * * *} \\
{[0.009]}\end{array}$ & $\begin{array}{c}0.066 \\
{[0.076]}\end{array}$ & $\begin{array}{c}0.096 \\
{[0.067]}\end{array}$ & $\begin{array}{l}0.022^{* * * *} \\
{[0.008]}\end{array}$ \\
\hline FINANCIAL_OPENNESS $_{t-1}$ & $\begin{array}{l}-0.035 \\
{[0.042]}\end{array}$ & $\begin{array}{c}-0.011 \\
{[0.045]}\end{array}$ & $\begin{array}{l}-0.000 \\
{[0.003]}\end{array}$ & $\begin{array}{c}-0.025 \\
{[0.045]}\end{array}$ & $\begin{array}{c}0.012 \\
{[0.053]}\end{array}$ & $\begin{array}{c}0.001 \\
{[0.003]}\end{array}$ \\
\hline $\mathrm{M} 2 / \operatorname{RESERVE}_{t-1}$ & $\begin{array}{c}0.687^{* * * *} \\
{[0.219]}\end{array}$ & $\begin{array}{c}0.472 \\
{[0.340]}\end{array}$ & $\begin{array}{c}0.095 \\
{[0.062]}\end{array}$ & $\begin{array}{c}0.670^{* * *} \\
{[0.247]}\end{array}$ & $\begin{array}{c}0.304 \\
{[0.362]}\end{array}$ & $\begin{array}{c}0.083 \\
{[0.070]}\end{array}$ \\
\hline Constant & $\begin{array}{l}-2.184^{* * * *} \\
{[0.387]}\end{array}$ & $\begin{array}{l}-0.685 \\
{[0.714]}\end{array}$ & $\begin{array}{l}0.087^{* * *} \\
{[0.039]}\end{array}$ & $\begin{array}{c}-2.184^{* * * *} \\
{[0.444]}\end{array}$ & $\begin{array}{l}-0.087 \\
{[0.943]}\end{array}$ & $\begin{array}{l}0.106^{* *} \\
{[0.050]}\end{array}$ \\
\hline \multicolumn{7}{|l|}{ First-stage coefficients } \\
\hline PROXIMITY_G7 $t-6, t-10$ & & $\begin{array}{l}1.210^{* * *} \\
{[0.266]}\end{array}$ & $\begin{array}{c}1.225^{* * *} \\
{[0.264]}\end{array}$ & & $\begin{array}{l}1.146^{* * *} \\
{[0.296]}\end{array}$ & $\begin{array}{l}1.163^{* * *} \\
{[0.294]}\end{array}$ \\
\hline MOVEMENT_G7 $7_{t-6, t-10}$ & & $\begin{array}{l}1.899^{* * * *} \\
{[0.520]}\end{array}$ & $\begin{array}{c}1.800^{* * * *} \\
{[0.548]}\end{array}$ & & $\begin{array}{l}1.710^{* * *} \\
{[0.538]}\end{array}$ & $\begin{array}{l}1.606^{* * *} \\
{[0.584]}\end{array}$ \\
\hline Observations & 2,383 & 2,383 & 2,383 & 2,234 & 2,234 & 2,234 \\
\hline $\begin{array}{l}\text { Wald test of exogeneity (p-value) } \\
\text { K-P weak identification (F-test) }\end{array}$ & & 0.010 & 23.016 & & & 15.892 \\
\hline K-P underidentification ( $\mathrm{p}$-value) & & & 0.000 & & & 0.000 \\
\hline Overidentification tets ( $\mathrm{p}$-value) & & & 0.161 & & & 0.301 \\
\hline
\end{tabular}

Notes: The table reports the regression coefficients and, in brackets, the associated clustered (at country level) standard errors. ${ }^{*}$ significant at $10 \%$; ${ }^{* *}$ significant at $5 \%$; ${ }^{* * *}$ significant at $1 \%$. At the bottom of the table we report some diagnostic tests. For the IV probit we report the p-value of the Wald test for the null hypothesis of no endogeneity. For the 2SLS we report the pvalue of: 1) the Kleibergen-Paap rk Wald F-statistic testing for weak identification; 2) the Kleibergen-Paap rk LM-statistic testing the null hypothesis that the excluded instruments are not correlated with the endogenous regressor; and 3) the Sargan test of overidentifying restrictions, testing the null hypothesis that the excluded instruments are not correlated with the error term (i.e. they are valid instruments). 


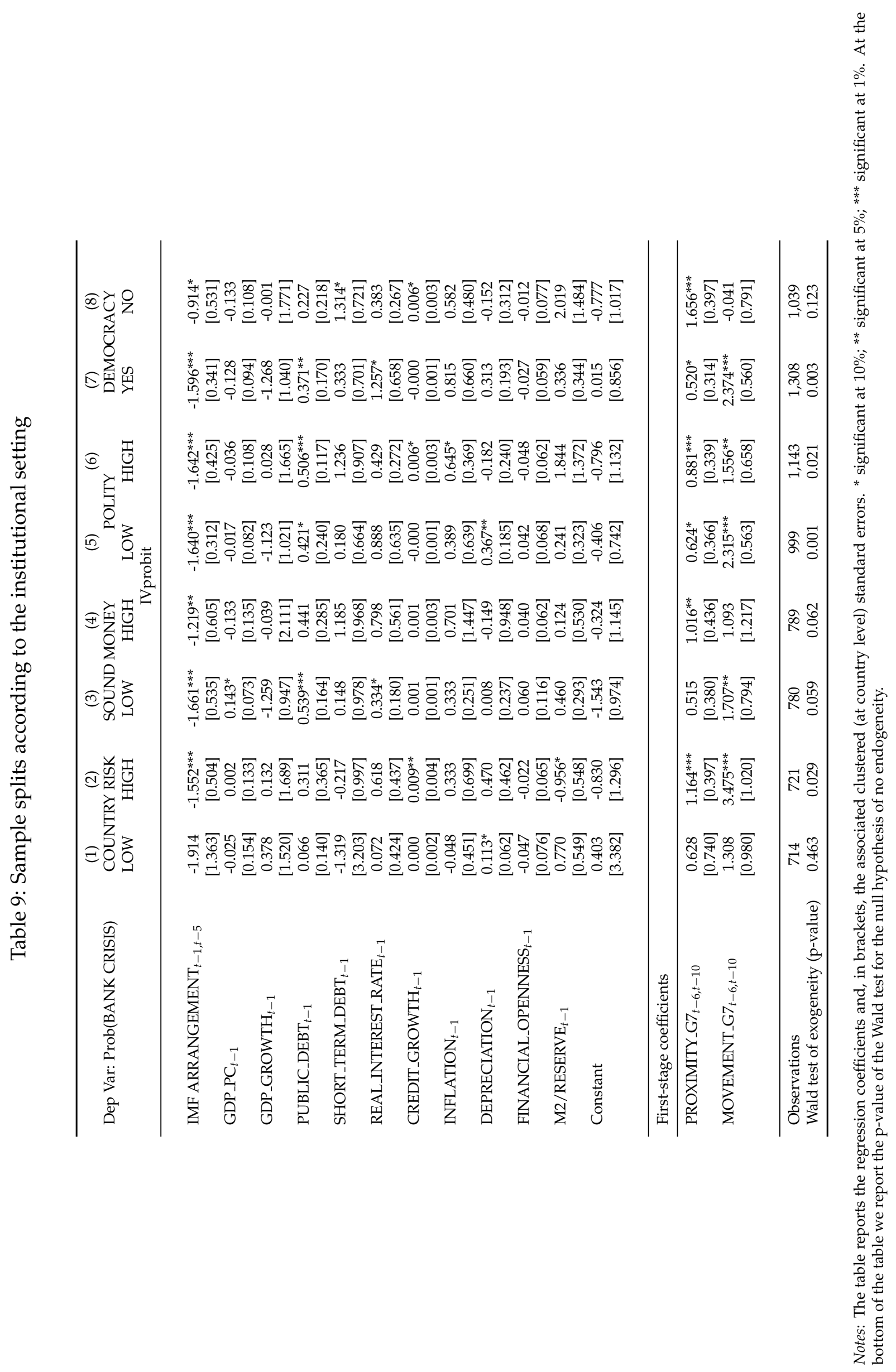




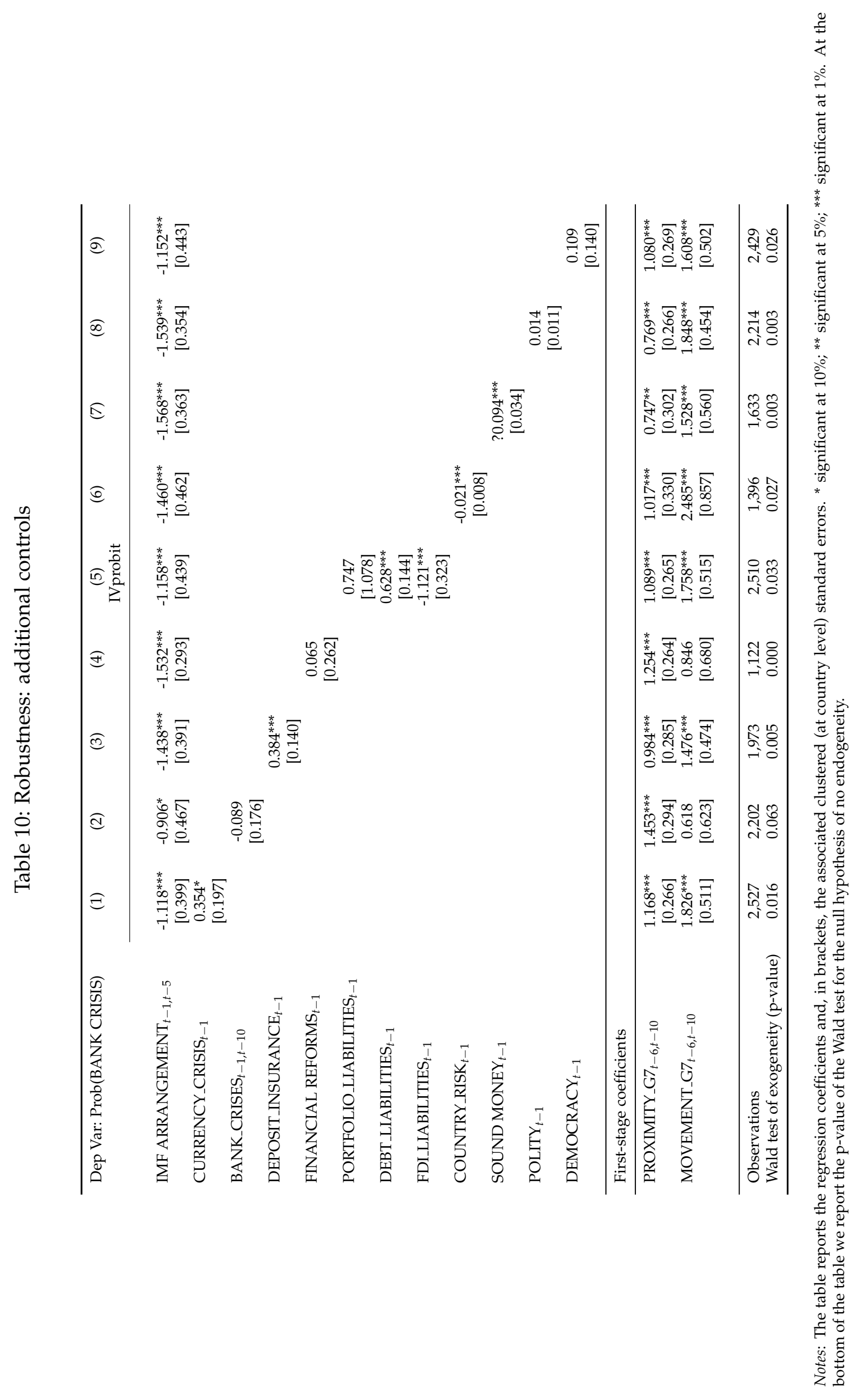

